Jurnal Ilmu dan Teknologi Kelautan Tropis, Vol. 8, No. 1, Hlm. 299-320, Juni 2016

VARIASI SPASIAL DAN TEMPORAL ARLINDO DI SELAT MAKASSAR

\title{
SPATIAL AND TEMPORAL VARIATION OF INDONESIAN THROUGHFLOW IN THE MAKASSAR STRAIT
}

\author{
Agus S. Atmadipoera ${ }^{*}$, Selfrida M. Horhoruw ${ }^{2}$, Mulia Purba ${ }^{1}$, dan Dwi Y. Nugroho ${ }^{3}$ \\ ${ }^{1}$ Departemen Ilmu dan Teknolologi Kelautan, FPIK IPB Bogor \\ ${ }^{2}$ Program Pasca Sarjana Ilmu Kelautan, IPB Bogor \\ ${ }^{3}$ Badan Riset Kelautan dan Perikanan, KKP Jakarta \\ *E-mail: atmadipoera_itk@ipb.ac.id
}

\begin{abstract}
Using outputs of INDESO model, this study investigated vertical structure, spatial and temporal variation of the Indonesian Throughflow in Makassar Strait (M-ITF). It was shown that the main axis of persistent southward jet of M-ITF formed a unique path following the western shelf slope along the strait, which was associated with a high kinetic energy $(K E)$ region from near-surface down to the thermocline layer. Furthermore, a drastic jump of KE appeared in the narrow and deep Libani Channel (near $\left.3^{\circ} S\right)$ where the strait's width shrinks significantly, thus an elevated flow velocity was needed to maintain transport volume balance. Here, maximum southward velocity at thermocline exceeded $1.2 \mathrm{~m} / \mathrm{s}$. Spatial pattern of M-ITF can be described by the first EOF mode which accounts for $79 \%$ of the total variances. It exhibited that contours of the flow amplitudes were similar to M-ITF path, and the largest amplitude was located near the Libani Channel. Out-of-phase relationship of the flow was found between M-ITF and eddies circulation that developed in the edges of the strait. Corresponding temporal fluctuation of the first EOF mode indicated that M-ITF variabilities varied from intraseasonal to inter-annual scales. Annual fluctuation of M-ITF was seen from EOF mode-2 (at thermocline layer) and mode-3 at lower-thermocline. Cross-spectra analysis revealed that variability of M-ITF (e.g. on annual scale) at northern entrance was highly coherent to the fluctuations of North Equatorial Current (NEC) and Mindanao Current (MC), suggesting that variability of M-ITF was remotely influenced by the Pacific low-latitude western boundary currents.
\end{abstract}

Keywords: INDESO model, Indonesian Throughflow, Makassar Strait, EOF, Cross-Spectra Analysis

\begin{abstract}
ABSTRAK
Dari data deret-waktu keluaran model INDESO, studi ini bertujuan mengkaji struktur menegak dan variasi spasial-temporal dari Arlindo di Selat Makassar (M-ITF). Terungkap bahwa sumbu utama jet M-ITF membentuk lintasan khas yang mengikuti lerengan tepi barat dari selat, serta dicirikan dengan nilai energi kinetik tinggi dari dekat permukaan sampai bawah termoklin. Lonjakan drastis dari nilai EK terjadi di bagian selat sempit, yaitu di Kanal Libani, dimana kecepatan aliran dari M-ITF meningkat pesat untuk menjaga keseimbangan volume angkutannya. Di kanal ini besaran kecepatan aliran mencapai maksimum di kedalaman termoklin lebih dari $1.2 \mathrm{~m} /$ detik. Variasi spasial dari M-ITF dapat digambarkan dengan EOF mode pertama yang menjelaskan $79 \%$ dari total ragam (variance), dimana terlihat amplitude dari aliran terjadi di sepanjang lintasannya, serta amplitude terbesar di sekitar Kanal Libani. Hubungan fase-terbalik dari aliran antara M-ITF dengan pusaran arus (eddies) yang terjadi di tepi barat (sekitar $1^{\circ} \mathrm{LU}$ ) dan tepi timur (sekitar $4^{\circ} \mathrm{LS}$ ) selat. Fluktuasi temporal yang bersesuaian dengan EOF mode pertama tersebut menunjukkan variabilitas M-ITF terjadi dari skala waktu intramusiman sampai inter-tahunan. Fluktuasi tahunan dari M-ITF terlihat pada EOF mode-2 (di lapisan termoklin) dan mode-3 di lapisan bawah termoklin. Analisis spektral-silang menunjukkan bahwa variabilitas M-ITF memiliki koherensi yang tinggi Arus Ekuator Utara dan Arus Mindanao. Sehingga dapat diduga bahwa fluktuasi M-ITF dipengaruhi secara jarak jauh (remotely) oleh sistem arus di tepi barat Pasifik.
\end{abstract}

Kata kunci: Model INDESO, Arus Lintas Indonesia, Selat Makassar, Analisis EOF, Spektra-Silang 


\section{PENDAHULUAN}

Sirkulasi laut Indonesia dipengaruhi secara signifikan oleh dua sistem arus utama, yaitu Arus Monsun Indonesia (Armondo) yang terbentuk sebagai respon terhadap angin Monsun yang berganti arah dua kali dalam setahun, serta Arus Lintas Indonesia (Arlindo) sebagai sistem arus yang persisten dari Samudera Pasifik ke Hindia yang melalui Laut Indonesia dan merupakan komponen penting dari sirkulasi termohalin global (Gordon, 1986; Ilahude dan Nontji, 1993). Laut Indonesia merupakan satu-satunya penghubung langsung antar-samudera di wilayah ekuator dunia, yang memungkinkan terjadi transfer bahang dan massa air dari Samudera Pasifik ke Hindia. Transfer oleh Arlindo ini dapat mempengaruhi neraca bahang dan massa di lapisan permukaan dan termoklin Samudera Hindia, yang selanjutnya berpengaruh terhadap variabilitas iklim dalam skala regional dan global (Gordon, 1986; Godfrey, 1996).

Arlindo Makassar masih menjadi kajian yang menarik bagi para peneliti kelautan dunia, karena merupakan cabang utama Arlindo (Gambar 1). Beberapa hasil kajian dari data pengukuran hidrografi, observasi mooring arus, serta pemodelan sirkulasi laut telah terungkap proses fisik, dinamika dan variabilitas Arlindo. Misalnya, Arlindo Makassar memberikan kontribusi hampir $70 \%$ dari rerata total volume transport Arlindo (Gordon et al., 2010). Arlindo Makassar utamanya membawa massa air yang berasal dari Pasifik Utara, yaitu massa air termoklin North Pacific Subtropical Water (NPSW) dan massa air bawah termoklin North Pacific Intermediate Water (NPIW) (Wyrtki, 1966; Illahude and Gordon, 1996; Atmadipoera et al., 2009). Intensifikasi besaran arus Arlindo Makassar ditemukan di lapisan termoklin, serta bervariasi secara musiman. Besarnya transport Arlindo Makassar selama periode Musim Timur (Juli - September) lebih kuat dibandingkan dalam periode Musim Barat (Desember - Februari) (Gordon et al., 2010;
Susanto et al., 2012). Model sirkulasi menunjukkan terjadi intensifikasi tepi barat dari Jet Arlindo Makassar di sepanjang lintasan selat ini (Mayer and Damm, 2012). Hasil pengukuran langsung dalam program EWIN-2013 menunjukkan bahwa massa air Arlindo Makassar (NPSW dan NPIW) bervariasi secara spasial dimana stratifikasi massa air itu lebih tegas karakternya di tepi barat dibanding dengan tepi timur selat, yang berasosiasi dengan penguatan Arlindonya (Horhoruw et al., 2015).

Variabilitas Arlindo terjadi dalam rentang skala-waktu yang luas, yang berkaitan dengan dinamika laut-atmosfer di wilayah Indo-Pasifik. Misalnya, dalam skalawaktu intra-musiman dan musiman, fluktuasi Arlindo berhubungan erat dengan dinamika laut-atmosfer di wilayah ekuator seperti Madden Julian Oscillation (MJO), kedatangan gelombang Kelvin Hindia dan Rossby Pasifik, serta Monsun Asia-Australia. Dalam skala-waktu antar-tahunan, Arlindo juga dipengaruhi oleh dinamika interaksi lautatmosfer di Samudera Pasifik dan Hindia, seperti fenomena El-Nino Southern Oscillation (ENSO) dan Indian Ocean Dipole (Meyers, 1996; Gordon, 2005; Kida and Wijffels, 2012; Shinoda et al., 2012). Fluktuasi arus dalam periode yang lebih panjang, seperti tahunan sangat erat berkorelasi dengan dinamika laut-atmosfer Monsun, dan periode antartahunan dengan fenomena ENSO dan IOD (Liu et al., 2015; Susanto et al., 2012).

Penelitian sebelumnya melaporkan bahwa fluktuasi arus dalam skala intra-seasonal dan semi-annual di kedalaman termoklin dan bawah termoklin di Selat Makassar berkorelasi erat dengan kedatangan coastally trapped gelombang Kelvin yang berasal dari wilayah ekuator Samudera Hindia (Sprintall et al., 2000; Susanto et al., 2012; Pujiana et al., 2014). Namun demikian, kemungkinan faktor penggerak fluktuasi Arlindo Makassar yang berasal dari remote forcing Samudera Pasifik masih belum diungkapkan secara tegas. Masumoto et al. (2001) melaporkan eksistensi eddies yang bergerak ke arah barat 
dalam skala intra-seasonal di Laut Sulawesi yang terbentuk karena ketidakstabilan arus di pintu masuk Laut Sulawesi. Eddies ini dapat mempengaruhi besarnya transport Arlindo yang masuk ke Selat Makassar, tetapi propagasi signal dalam skala intra-seasonal tersebut kedalam laut interior Indonesia mengalami peluruhan secara cepat (damped).

Tujuan makalah ini adalah untuk mengkaji siklus tahunan Arlindo Makassar, struktur spasial dan variasi temporal Arlindo Makassar di kedalaman dekat permukaan, termoklin dan bawah termoklin, serta koherensi fluktuasi Arlindo Makassar dengan arus di kawasan Indo-Pasifik.

\section{METODE PENELITIAN}

\subsection{Waktu dan Tempat Penelitian}

Penelitian ini dilakukan mulai dari bulan November 2015 sampai dengan April 2016 di Laboratorium Oseanografi Fisika, Dept. ITK FPIK IPB. Lokasi penelitian berada di wilayah Selat Makassar, yang dibatasi pada wilayah antara $6^{\circ} \mathrm{LS}-3^{\circ} \mathrm{LU}$ dan $115^{\circ} \mathrm{BT}$ $120.5^{\circ} \mathrm{BT}$, di bagian selatan dibatasi oleh lintang $4^{\circ} \mathrm{LS}$ dan di bagian utara pada lintang $2^{\circ} \mathrm{LU}$ (Gambar 1).

\subsection{Bahan dan Data}

\subsubsection{Keluaran Model INDESO}

Hasil simulasi model sirkulasi umum laut dengan konfigurasi INDESO (Infrastructure Development of Space Oceanography) dari tahun 2007-2014 digunakan dalam makalah ini. Dibandingkan dengan sistem pemodelan laut serupa di wilayah Indonesia (misal HYCOM, OFES), maka model INDESO memiliki beberapa keunggulan, seperti telah diterapkan forcing pasang-surut baroklinik dan barotrofik secara eksplisit, forcing atmosfer dengan resolusi temporal dan spasial tinggi, pengaturan topografi dasar laut pada wilayah selat sempit, serta validasi yang intensif hasil simulasi arus dan massa air dengan data lapangan dengan hasil yang memuaskan (Tranchant et al., 2015). Model INDESO menggunakan sistem pemodelan
NEMO (Madec, 2008). Secara lengkap konfigurasi dan validasi Model INDESO dijelaskan dalam Tranchant et al. (2015). Penjelasan ringkas dari konfigurasi model ini memiliki resolusi horisontal $1 / 12^{\circ}$ atau sekitar $9.25 \mathrm{~km}$ dengan 50 level vertikal dimana resolusi vertikal di dekat permukaan lebih rapat (sekitar $1 \mathrm{~m}$ ), dan semakin renggang dengan bertambah kedalaman. Data bathymetri didasarkan pada data ETOPO2 Versi 2' dan GEBCO Versi 1'. Penggerak atmosfer beresolusi temporal tinggi (3-jam) diperoleh dari data European Centre for MediumRange Weather Forecasts (ECMWF). Penggerak pasang-surut barotropik di batas terbuka untuk 10 komponen pasut utama diperoleh dari TPXO7 (Egbert and Erofeeva, 2002). Penggerak pasang surut diterapkan secara eksplisit maupun secara implisit (parameterisasi), sehingga proses fisik percampuran dapat dimodelkan secara akurat.

Model INDESO merupakan salah satu program kelautan dari Kementrian Kelautan dan Perikanan, yang didukung oleh 2 lembaga riset kelautan Europa (MercatorOcean dan Collecte Localisation Satellites CLS) untuk pengembangan oseanografi operasional di Indonesia. Pusat pengendali program operasional oseanografi INDESO berpusat di Balai Observasi dan Pemodelan Laut (BPOL) Bali. Keluaran model INDESO yang digunakan dalam penelitian ini, berupa variabel komponen arus zonal dan meridional 3-dimensi dengan rataan harian dari tahun 2007 sampai 2014.

\subsection{Analisis Data}

Untuk mengkaji struktur dan variabilitas Arlindo Makassar dianalisis dengan metode Empirical Orthogonal Function (EOF) (Thomson and Emery, 2014), sehingga data deret waktu arus tersebut bisa dianalisis secara temporal dan spasial di seluruh bagian Selat Makassar. Metode EOF diaplikasikan pada komponen arus meridional (v) yang merupakan komponen arus dominan karena konfigurasi selat dalam orientasi utara-selatan. Aliran Arlindo Makassar dari Samudera Pa- 


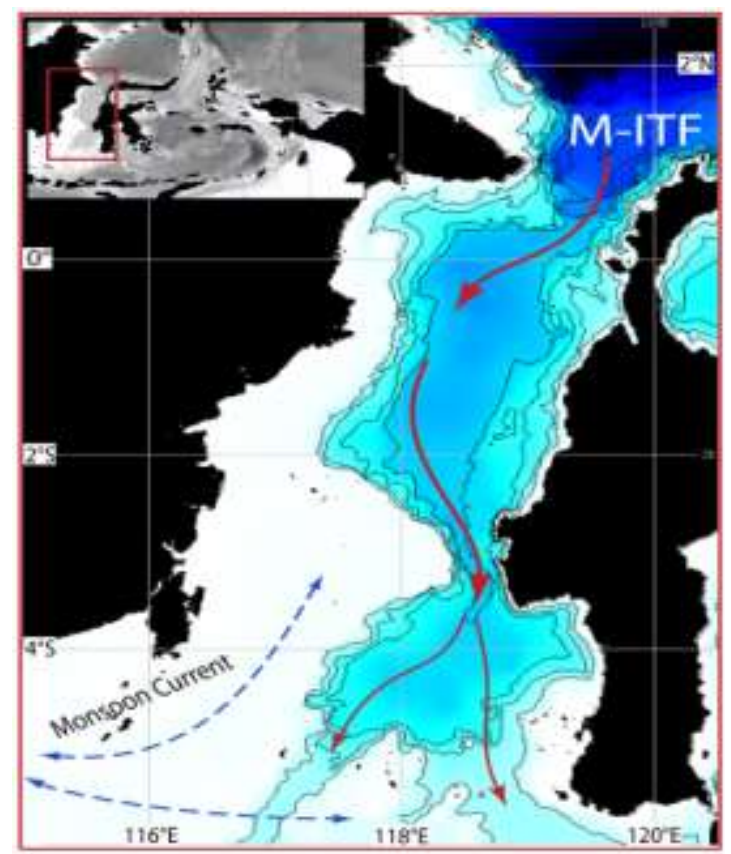

Gambar 1. Peta wilayah studi di Selat Makassar dengan bathymetri dasar laut dengan kontur interval 500 m. Skema sirkulasi Arlindo Makassar dan Arus Muson Laut Jawa. (sumber: Bathymetri GEBCO).

sifik menuju Samudera Hindia yang melewati selat ini didominasi oleh komponen utara-selatan (Susanto et al., 2012; Gordon et al., 2012; Mayer dan Damm, 2012; Horhoruw et al., 2015).

Analisis EOF menghasilkan pola spasial yang menunjukkan osilasi tetap dari suatu perairan, sedangkan evolusi waktu yang ditunjukan dari hasil principal component (PC) menunjukan bagaimana pola tersebut berfluktuasi terhadap waktu. Menurut Hanachi et al. (2007), perhitungan EOF dilakukan berdasarkan persamaan sebagai berikut:

$$
X(t, s)=\sum_{k=1}^{M} c_{k}(t) u_{k}(s)
$$

dimana $X(t, s)$ adalah data deret-waktu sebagai fungsi waktu (t) dan ruang (s); $\mathrm{M}$ merupakan jumlah moda yang terdapat pada bidang dengan menggunakan suatu set optimal dari fungsi ruang $u_{k}(s)$ dan ekspansi fungsi waktu $c_{k}(t)$.

Untuk melihat kekuatan signal dan periodisitas fluktuasi M-ITF dilakukan analisis Power Spectral Density (PSD) dengan selang kepercayaan $95 \%$ dan menggunakan panjang segmen sebesar 512 data menggunakan persamaan (Bendat dan Piersol, 2000), yang dimulai dari perhitungan transformasi Fourier cepat (FFT) sebagai berikut :

$$
X\left(f_{k}\right)=h \sum_{i=0}^{N-1} \exp \left[-1 \frac{2 \pi k t}{N}\right]
$$

Energi densitas hasil perhitungan FFT dari moda ekspansi EOF adalah sebagai berikut:

$$
S_{x}=\frac{2 h}{N}\left|X\left(f_{k}\right)\right|^{2}
$$

dimana $X\left(f_{k}\right)$ adalah deret waktu koefisien ekspansi EOF, $h$ adalah interval data EOF, $N$ adalah data EOF dari tahun 2007-2014 dan $f_{k}$ adalah frekuensi ke- $k$.

Selain komponen arus meridional (v), magnitude aliran Arlindo Makassar diestimasi dalam bentuk energi kinetik (EK), yang dihitung menurut persamaan:

$$
E K=\frac{1}{2}\left(u^{2}+v^{2}\right) / \text { unit mass } a \text {, dengan } \mathrm{u} \text { dan }
$$
$\mathrm{v}$, masing-masing, adalah komponen arus 
zonal dan meridional. Dari persamaan energi kinetik (EK) terlihat bahwa semakin besar magnitude kecepatan arus ( $\mathrm{u}$ dan $\mathrm{v}$ ), maka nilai EK akan semakin besar juga. Nilai EK yang tinggi diharapkan terjadi di sepanjang sumbu utama dari aliran Arlindo Makassar.

Analisis spektra-silang (cross-PSD) digunakan untuk menganalisis hubungan antara fluktuasi dua atau lebih variabel. Dalam makalah ini, analisis spektra-silang dilakukan antara arus (dinyatakan dengan besaran energi kinetik EK), di pintu utara Selat Makassar dengan sistem arus di kawasan IndoPasifik di tiga kedalaman berbeda (tercampur, termoklin, dan bawah termoklin). Analisis spektra-silang mencakup perhitungan kospektral energi, koherensi dan beda fase. Kospektral energi menunjukkan besarnya fluktuasi energi pada periode yang sama dari kedua variabel tersebut. Apabila arus di bagian "hulu" Arlindo mempengaruhi arus di bagian "hilir" Arlindo, maka keduanya akan menunjukkan hubungan yang kuat antara kedua variabel (nilai koherensi yang tinggi). Beda fase menunjukkan perbedaan selang waktu antara kedua variabel. Beda fase positif menunjukkan bahwa fluktuasi variabel yang mempengaruhi mendahului (lead) variabel yang dipengaruhi, sedangkan beda fase negatif menunjukkan bahwa fluktuasi variabel yang dipengaruhi mendahului variabel yang mempengaruhi (lag) (Thomson and Emery, 2014). Time lag adalah waktu yang diperlukan oleh variabel yang dipengaruhi untuk berespon.

Menurut Bendat dan Piersol (2010), kospektrum energi $\left(G_{x y}\left(f_{k}\right)\right)$, koherensi $\left(\gamma_{x y}^{2}\left(f_{k}\right)\right)$, dan beda fase $\left(\theta_{x y}\left(f_{k}\right)\right)$ dari dua pasang komponen Fourier dari data deret waktu $x_{n}$ dan $y_{n}$, pada setiap selang waktu $\Delta t$, dihitung dengan formulasi sebagai berikut:

$G_{x y}\left(f_{k}\right)=\frac{2 \Delta t}{T}\left|X\left(f_{k}\right) * Y\left(f_{k}\right)\right|$

dimana: $X\left(f_{k}\right)=$ Komponen Fourier dari $x_{n}$ $Y\left(f_{k}\right)=$ Komponen Fourier dari $y_{n}, T=$ Periode data Fungsi koherensi $\left(\gamma_{x y}^{2}\left(f_{k}\right)\right)$ dihitung menggunakan persamaan:

$\gamma_{x y}^{2}\left(f_{k}\right)=\frac{\left|G_{x y y}\left(f_{k}\right)\right|^{2}}{s_{x}\left(f_{k}\right) s_{y}\left(f_{k}\right)} \ldots \ldots \ldots \ldots \ldots \ldots \ldots$

dimana:

$S_{x}\left(f_{k}\right)=$ Densitas energi $X\left(f_{k}\right), S_{y}\left(f_{k}\right)=$ Densitas energi $Y\left(f_{k}\right)$, Nilai beda fase $\left(\theta_{x y}\left(f_{k}\right)\right)$ dihitung menggunakan persamaan berikut:

$\theta_{x y}\left(f_{k}\right)=\tan ^{-1}\left[\frac{Q_{x y}\left(f_{k}\right)}{c_{x y}\left(f_{k}\right)}\right]$

dimana: $Q_{x y}\left(f_{k}\right)=$ Nilai imajiner dari $G_{x y}\left(f_{k}\right), C_{x y}\left(f_{k}\right)=$ Nilai nyata dari $G_{x y}\left(f_{k}\right)$

\section{HASIL DAN PEMBAHASAN}

\subsection{Validasi Model dengan Data Obser- vasi}

Validasi model arus dilakukan dengan data hasil mooring arus yang diukur di Kanal Libani dari tahun 2007 sampai 2009 (Susanto et al., 2013). Arus komponen meridional (v) dari model dan data mooring di Kanal Libani selama tahun 2007-2009 disajikan pada Gambar 2. Arus hasil simulasi INDESO menunjukkan pola yang mirip dengan arus hasil pengukuran lapangan. Pola variasi musiman arus dengan magnitude arus maksimum terjadi dalam periode Musim Timur (Juli-September), dan magnitude arus maksimum kedua terjadi dalam bulan AprilMei. Selain itu, pola yang mirip juga terjadi pada kecepatan arus minimum dalam bulan November-Desember dan pada sekitar bulan Mei (Gambar 2).

Hasil pengukuran in situ menunjukkan terjadi intensifikasi Arlindo Makassar antara dekat permukaan sampai bawah termoklin, dengan lapisan arus maksimum di termoklin (Gambar 2b). Hasil model menunjukkan ekstensi kecepatan arus maksimum lebih luas dari dekat permukaan sampai lapisan bawah termoklin, dengan lapisan kecepatan arus maksimum di bagian atas termoklin. Secara umum, pola distribusi arus dan 


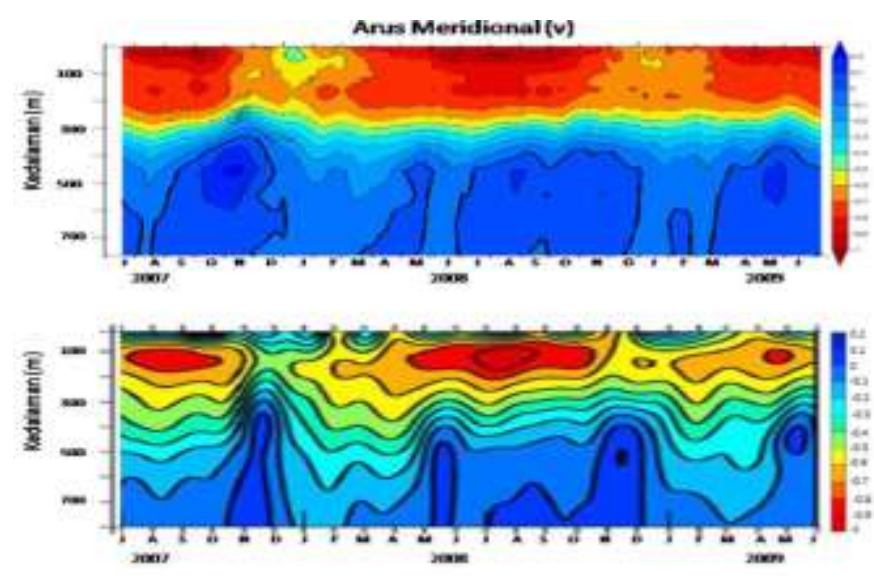

(a)

(b)

Gambar 2. Data deret-waktu arus komponen meridional di Kanal Libani, Selat Makassar dari tahun 2007 sampai 2009, (a) dari hasil simulasi INDESO; dan (b) along-strait velocity dari pengukuran in situ (Gambar 1b diambil dari Susanto et al., 2012).

variasi musiman antara hasil model dan observasi di Kanal Libani cukup sejalan (good agreement). Dengan demikian, keluaran model INDESO selanjutnya dapat digunakan untuk melengkapi (complement) data observasi dalam menganalisis struktur dan variabilitas Arlindo Makassar dalam skala spasial dan temporal yang lebih luas.

\subsection{Siklus Tahunan Arlindo di Selat Ma- kassar}

Siklus tahunan Arlindo Makassar pada 3 level kedalaman yang mewakili lapisan tercampur $(25 \mathrm{~m})$, termoklin $(92 \mathrm{~m})$ dan bawah termoklin $(318 \mathrm{~m})$ menunjukkan pola aliran yang konsisten serta menampilkan 3 pola sirkulasi yang unik (Gambar 3 - 5). Pertama, pola aliran Arlindo di sepanjang sumbu utamanya berkelok-kelok hampir mengikuti lereng topografi dasar laut di sepanjang tepi barat selat. Dari pintu utara selat, aliran Arlindo mengarah ke baratdaya sampai sekitar lintang $2^{\circ} \mathrm{LS}$. Kemudian, alirannya berbelok ke arah tenggara menyusuri lereng topografi dasar laut (dangkalan) Kalimantan. Aliran ini mengarah ke Kanal Libani yang sempit di sekitar lintang $3^{\circ} \mathrm{LS}$, dimana kecepatan alirannya meningkat secara drastis untuk mengimbangi penyempitan kanal terhadap besar debit Arlindo sebelum masuk kanal. Di bagian selatan selat (ke arah selatan dari $\left.4^{\circ} \mathrm{LS}\right)$, terjadi partisi aliran Arlindo pada kanal barat dan kanal timur yang sempit dan dalam.

Kedua, terbentuk pusaran arus (eddies) di tepi selat baik di sisi barat maupun sisi timur selat. Pada level $25 \mathrm{~m}$, terbentuk 2 eddies di tepi barat selat (sekitar $0-1^{\circ} \mathrm{LU}$ ) dan di tepi timur selat di sekitar $4^{\circ}$ LS. Pada level $92 \mathrm{~m}$, terbentuk 4 eddies 2 di tepi barat selat (sekitar $0-1^{\circ} \mathrm{LS}^{\circ}$ dan sekitar $4^{\circ} \mathrm{LS}$ ) serta di tepi timur selat sekitar $2^{\circ} \mathrm{LS}$ dan $4^{\circ} \mathrm{LS}$. Di level $318 \mathrm{~m}$, eddies yang terbentuk lebih tegas terjadi di tepi barat selat di sekitar $4^{\circ} \mathrm{LS}$. Arah pusaran arus ini ada yang bersifat searah jarum jam ataupun berlawanan arah jarum jam (Gambar 3-5). Wilayah terbentuknya pusaran arus ini umumnya terjadi di tepi batas dengan aliran Arlindo, sehingga diduga eddies ini terbentuk sebagai respon dari aliran Arlindo. Misalnya, dari hasil animasi data ini, pusaran arus searah jarum jam (clockwise eddies) yang terbentuk di tepi barat selat di sekitar $0-1^{\circ} \mathrm{LU}$ diduga karena dipicu oleh aliran Arlindo kuat ke arah baratdaya yang menyeret massa air di tepi batas alirannya yang berada di bawah tanjung (sekitar $1^{\circ} \mathrm{LU}$ ). Hal ini dapat dijelaskan secara sederhana karena kesinambungan aliran fluida mengharuskan massa air yang terseret oleh aliran Arlindo tersebut harus digantikan oleh massa air sekitarnya sehingga timbul aliran yang membenbentuk pusaran arus antisiklonik tersebut. 
Ketiga, besaran kecepatan Arlindo menunjukkan variasi musiman yang jelas, dimana dalam periode Musim Timur (JuliSeptember) nilai energi kinetik (EK) lebih kuat dibandingkan dengan EK pada Musim Barat (Desember-Februari). Semakin tinggi EK semakin kuat kecepatan alirannya. Misalnya, terjadi di Kanal Libani yang sempit (Gambar 3-5). Pada Musim Timur, arus maksimum pada Kanal Libani sebesar 1.45 m/s dan lebar jet Arlindo sebesar $150 \mathrm{~km}$ yang dihitung pada bulan September, sedangkan arus terendah terjadi pada Musim Barat dengan arus maksimum yang ditemukan selama Musim Barat pada Kanal Libani sebesar $0.91 \mathrm{~m} / \mathrm{s}$ dan lebar jet Arlindo pada wilayah $1^{\circ} \mathrm{LS}$ adalah $132 \mathrm{~km}$ pada bulan Februari. Lemahnya arus permukaan pada Musim Barat disebabkan adanya tekanan massa air dari selatan SM yang menghambat aliran massa air permukaan dari Samudera Pasifik menuju Samudera Hindia, sedangkan pada Musim Timur gradien ke utara berkurang akibat pembalikan arah angin sehingga arus permukaan menguat (Gordon et al., 2003).

Perkembangan eddies di bagian utara selat bervariasi secara musiman, dimana magnitude eddies dan nilai EK mencapai maksimum dalam periode Musim Timur (Juli- September) dan kekuatan maksimum kedua terjadi pada bulan Maret dengan besar EK pada wilayah eddies mencapai 0.03 $\mathrm{m}^{2} / \mathrm{s}^{2}$. Eddies terbentuk kuat dengan pusaran mendekati pesisir selat selama bulan Maret, dan bergeser menjauhi pesisir sejauh $40 \mathrm{~km}$ selama bulan Agustus-September. Pada wilayah selatan, eddies di sisi timur jet Arlindo memiliki pusaran maksimum selama bulan Oktober dan November dan kekuatan maksimum kedua ditemukan pada bulan Maret dengan EK mencapai $0.025 \mathrm{~m}^{2} / \mathrm{s}^{2}$.

Hasil model INDESO menunjukan aliran pada cabang barat mulai melemah pada bulan November, hingga mencapai nilai minimum pada bulan Januari dengan tidak terlihat adanya percabangan di bagian barat. Hal ini dipengaruhi oleh aliran yang berasal dari selatan seperti yang dijelaskan oleh Fang et al. (2010) dan Gordon et al. (2003). Selama musim peralihan 1, aliran massa air permukaan dari utara menguat menghilangkan efek gradien tekanan massa air dari Laut Jawa sehingga arus dan EK kembali menguat pada cabang bagian barat dan mencapai nilai maksimum pada Musim Timur.

Lebar maksimum aliran Arlindo Makassar di lapisan termoklin (Gambar 4) ditemukan pada bulan Agustus dan September dengan kecepatan arus maksimum di Kanal Libani adalah $1.47 \mathrm{~m} / \mathrm{s}$ dan lebar jet Arlindo yang diukur pada lintang $1^{\circ} \mathrm{LS}$ adalah $85 \mathrm{~km}$ dalam bulan September. Pada periode Musim Barat saat Arlindo Makassar melemah, arus jet paling rendah ditemukan pada bulan Januari dengan kecepatan arus maksimum pada Kanal Libani berkurang menjadi $0.71 \mathrm{~m} / \mathrm{s}$ serta lebar jet arus Arlindo sebesar $48 \mathrm{~km}$. Variasi musiman dari Arlindo SM hasil model tersebut sangat konsisten dan sesuai dengan hasil observasi dan pemodelan sebelumnya (Susanto et al., 2012; Shinoda et al., 2012; Gordon et al., 2012).

Siklus tahunan aliran Arlindo Makassar pada kedalaman bawah termoklin (Gambar 5) menunjukan kekuatan aliran yang semakin lemah. Jet utama Arlindo SM bawah termoklin dibatasi oleh nilai energi kinetik, EK $>0.015 \mathrm{~m}^{2} / \mathrm{s}^{2}$ (Gambar 5). Vektor arus serta EK pada kedalaman bawah termoklin bernilai maksimum dalam bulan Juli dengan lebar jet Arlindo yang diukur pada sepanjang $1^{\circ} \mathrm{LS}$ adalah sebesar $91 \mathrm{~km}$. Arus dan EK menjadi lemah dalam bulan November dan Desember dengan lebar jet Arlindo pada bulan November sekitar $56 \mathrm{~km}$. Shinoda et al. (2012) menyatakan kekuatan transpor Arlindo menuju selatan melemah selama bulan April-Mei dan Oktober-November yang disebabkan variasi angin di daerah tropis Samudera Hindia. Selain itu masuknya gelombang Kelvin semi tahunan yang ditemukan pada EOF Moda-3 turut berpengaruh.

Pada kedalaman bawah termoklin, ditemukan eddies pada wilayah timur jet Arlindo di utara Kanal Libani serta pada sisi barat jet Arlindo pada Selatan Kanal Libani. 

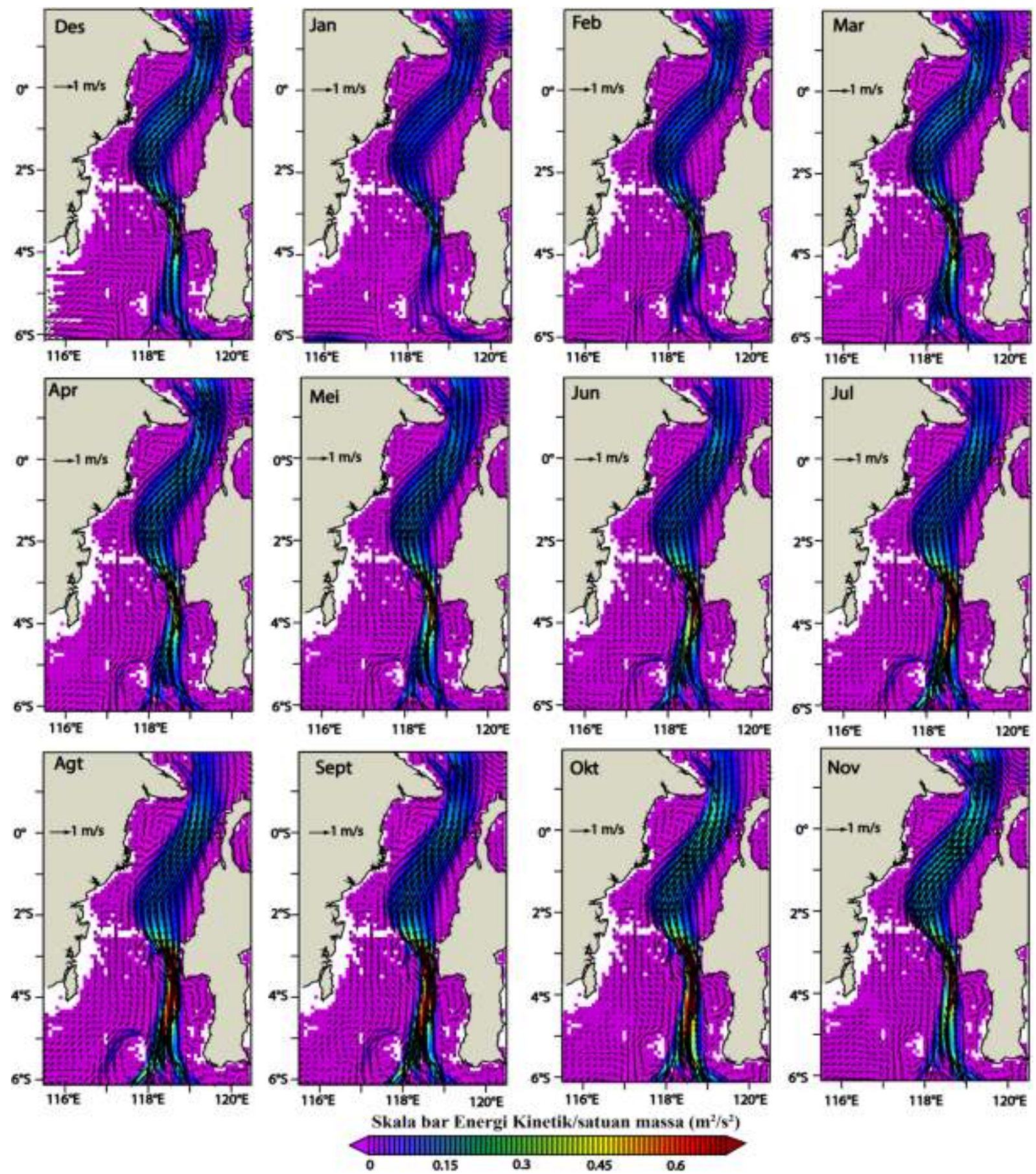

Gambar 3. Rataan bulanan energi kinetik (EK) dan vektor arus dari keluaran Modal INDESO (2007-2013) di kedalaman 25 m di Selat Makassar. Warna menunjukan nilai EK per unit massa. Sumbu utama aliran Arlindo makassar ditunjukan oleh kontur EK $>0.05 \mathrm{~m}^{2} / \mathrm{s}^{2}$.

Eddies di selatan selat menguat pada sekitar bulan Maret dan April. Kuatnya massa air yang masuk pada Musim Timur turut menguatkan eddies yang terbentuk pada kedalaman termoklin, yang menunjukkan kekuat- an arus serta lebar maksimum pada bulan Juli-September, namun melemah selama Musim Barat hingga awal musim peralihan 1. Siklus tahunan Arlindo menunjukan ada hubungan antara eddies yang terbentuk pada 

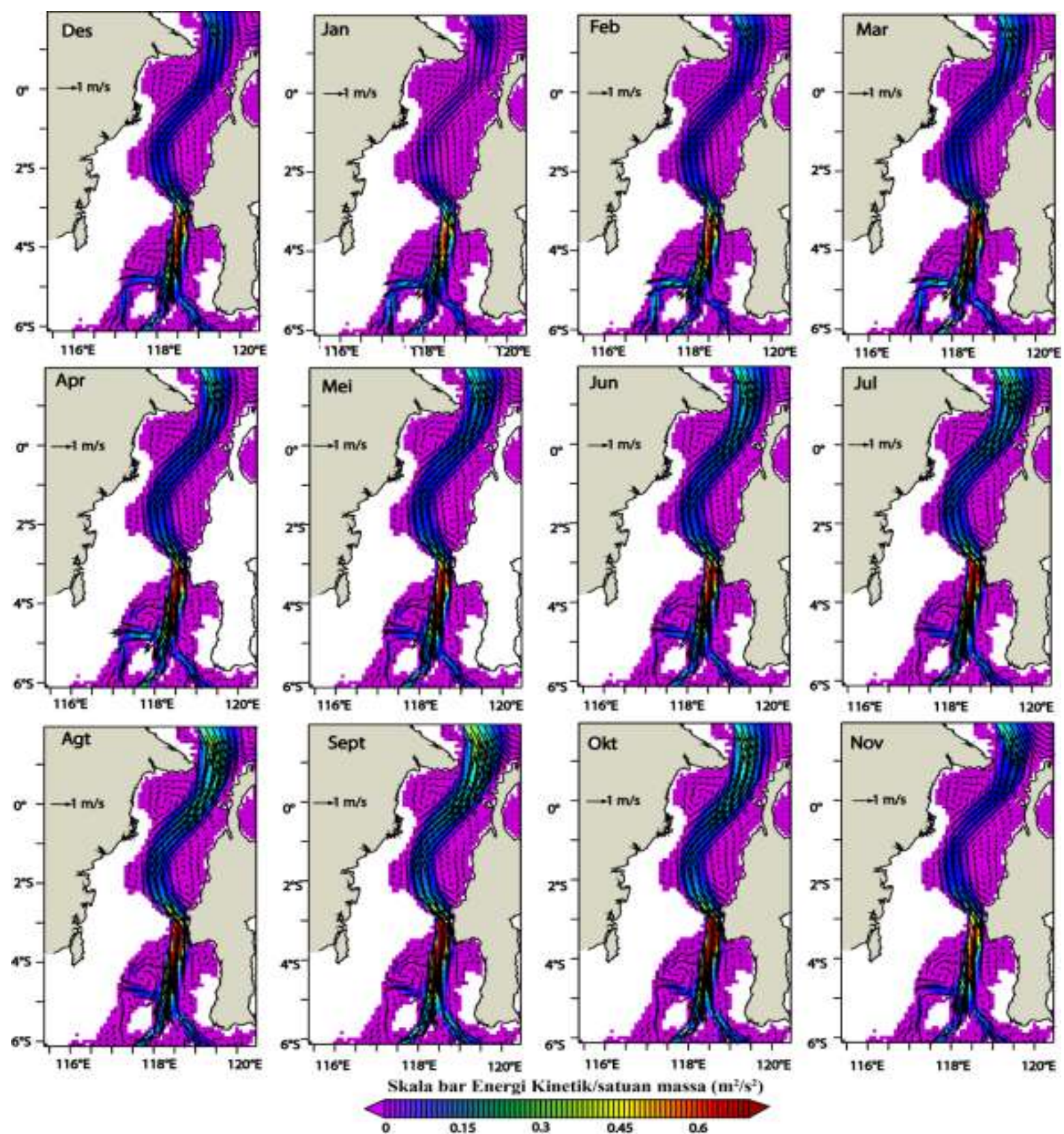

Gambar 4. Seperti pada Gambar 2, tetapi di kedalaman 92 m (termoklin).

selatan Kanal Libani di sisi barat dengan kekuatan aliran yang mengalir memasuki Selat Lombok, terutama yang melalui cabang barat. Pada saat eddies di sisi barat menguat, maka aliran yang melewati cabang barat semakin lemah, dan sebaliknya ketika eddies melemah aliran yang melewati sisi barat menguat. Hal ini bergantung pada kekuatan Arlindo yang diduga berbenturan dengan Dewakang sill sehingga menghasilkan resirkulasi arus yang membentuk eddies. Hasil pemodelan menunjukkan bahwa resirkulasi eddies dari jet Arlindo Makassar dalam Musim Timur dapat mempengaruhi intensitas upwelling yang terjadi di bagian baratdaya lepas pantai Makassar (Atmadipoera \& Widyastuti, 2014), sehingga mempengaruhi luasan penyebaran massa air dengan suhu permukaan laut yang rendah dan klorofil-a tinggi selama periode upwelling. (Syahdan et al,. 2014, Nababan et al., 2016). 

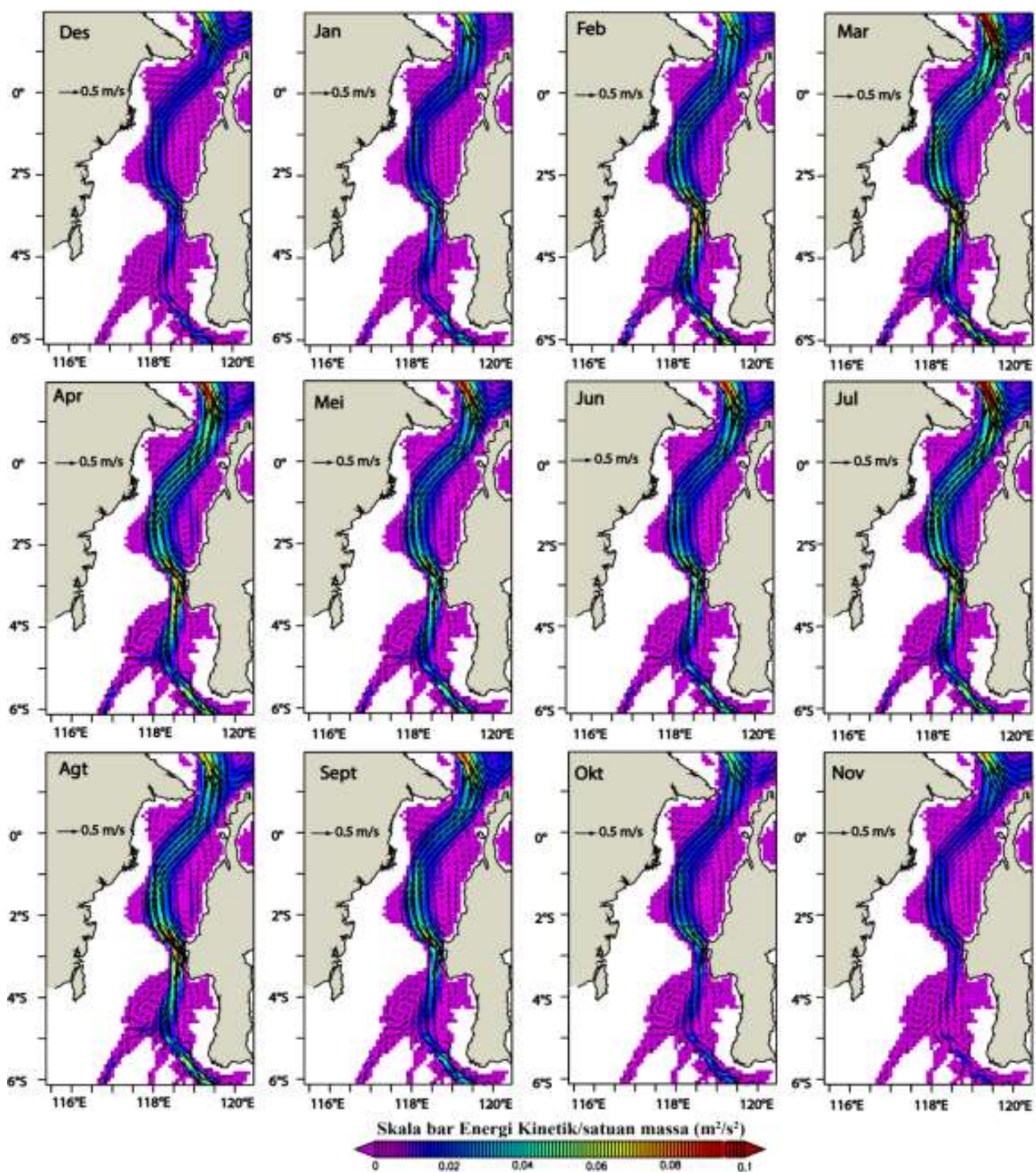

Gambar 5. Seperti pada Gambar 3, tetapi di kedalaman 318 m (bawah termoklin).

\subsection{Struktur Vertikal Arlindo Makassar}

Arlindo Makassar dicirikan dengan sebaran energi kinetik (EK) di sepanjang sumbu utama lintasannya dengan rerata EK yang relatif tinggi $\left(>0.15 \mathrm{~m}^{2} / \mathrm{s}^{2}\right.$ per unit massa) utamanya di lapisan termoklin, serta nilai EK yang sangat tinggi di kawasan sempit sekitar Kanal Libani (Gambar 6a). Di dekat pintu utara selat (lokasi A) rerata energi kinetik yang relatif tinggi berada pada keda- laman antara $50 \mathrm{~m}$ dan $200 \mathrm{~m}$. Semakin kearah selatan, nilai EK yang relatif tinggi cenderung terbentuk di lapisan termoklin. Hal ini berarti besaran kecepatan Arlindo yang terbentuk maksimum di lapisan termoklin. Peningkatan nilai EK yang drastis di kanal Libani yang mencapai maksimum sampai $>0.7 \mathrm{~m}^{2} / \mathrm{s}^{2}$ per unit massa di kedalaman sekitar $50 \mathrm{~m}$. Dalam arah vertikal nilai EK yang tinggi mencapai kedalaman sekitar 200 


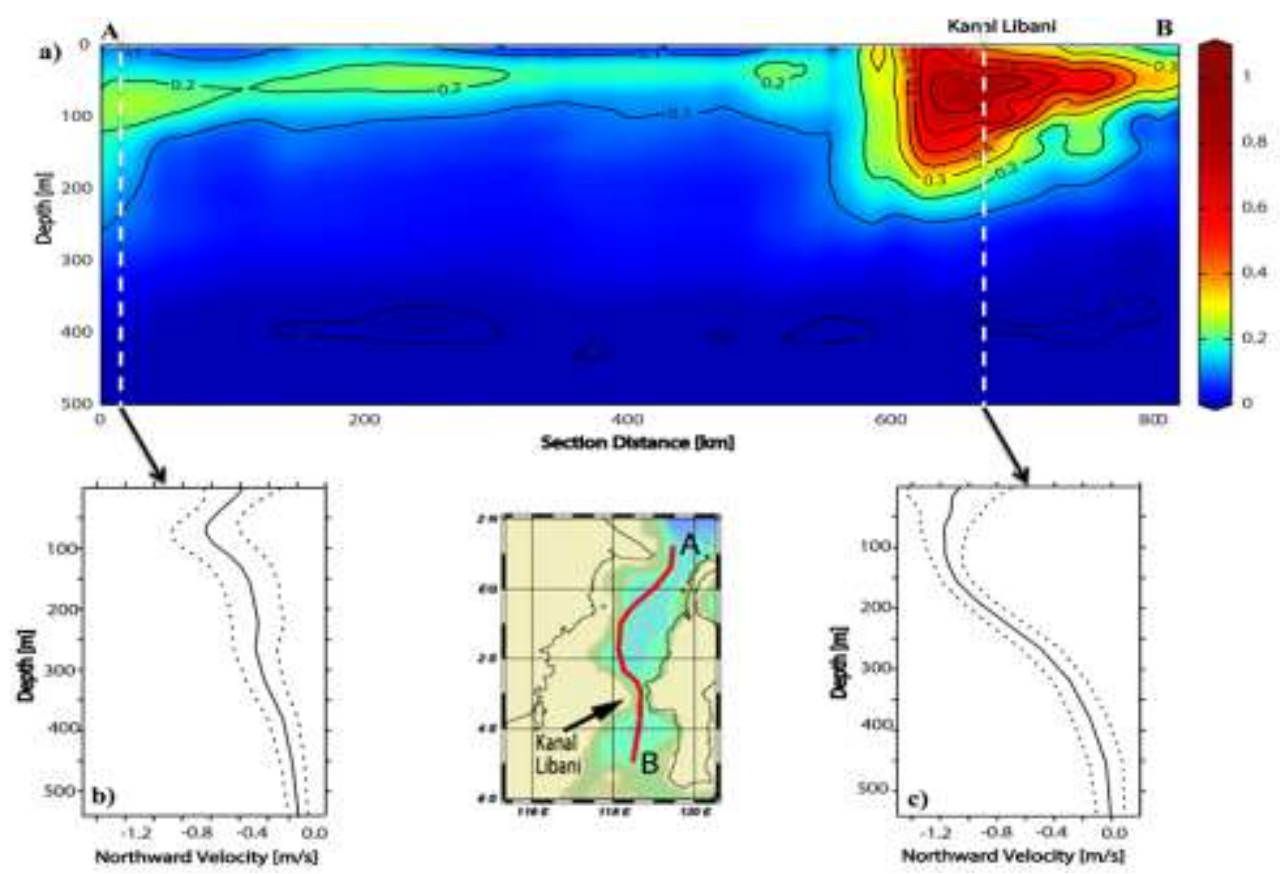

Gambar 6. Penampang rerata (2007-2013) energi kinetik per unit massa di sepanjang sumbu utama lintasan Arlindo Makassar (a); rerata profil komponen arus meridional (v) di pintu utara selat (b); dan di dekat Kanal Libani (c).

$\mathrm{m}$, dan panjang lintasan utara-selatan dari nilai EK tinggi di sekitar Kanal Libani mencapai sekitar $200 \mathrm{~km}$ (Gambar 6a).

Profil menegak rerata komponen arus meridional (utara-selatan) di lokasi yang mewakili pintu utara selat (Gambar 6b) menunjukkan semakin bertambah kedalaman, kecepatan arus semakin meningkat dan mencapai maksimum $(0.6 \mathrm{~m} / \mathrm{s})$ di sekitar kedalaman $75 \mathrm{~m}$ (lapisan termoklin). Profil arus meridional yang kuat di Kanal Libani (jet Arlindo) terbentuk kecepatan arus sekitar 1 $\mathrm{m} / \mathrm{s}$ di dekat permukaan dan terus meningkat magnitudenya sampai $1.2 \mathrm{~m} / \mathrm{s}$ di sekitar kedalaman 75-150 m.

\subsection{Variasi Spasial dan Temporal Arlindo Makassar}

\subsubsection{Kedalaman Dekat Permukaan (25 m)}

Struktur spasial Arlindo Makassar pada kedalaman $25 \mathrm{~m}$ untuk 3 mode EOF teratas dengan kontribusi nilai explained $v a$ riances sebesar $88.5 \%$ disajikan pada Gambar 7. Mode-1 memberikan nilai explained variance sebesar $79.1 \%$, yang dicirikan oleh nilai koefisien EOF positif yang memanjang dari bagian utara selat sampai selatan selat, serta terjadi peningkatan koefisien EOF yang drastis di kawasan Kanal Libani (Gb. 7a). Struktur spasial mode-1 ini dianggap representasi dari sumbu utama aliran Arlindo Makassar dan peningkatan Jet Arlindo Makassar di Kanal Libani. Pada mode-2 (explained variances $6 \%$ ) koefisien EOF positif masih dominan di sepanjang sumbu utama lintasan Arlindo, tetapi terdapat koefisien EOF negatif (fase berlawanan) di tepi barat selat sekitar $1^{\circ} \mathrm{LS}-1^{\circ} \mathrm{LU}$ dan di tepi timur selat sekitar $4^{\circ} \mathrm{LS}$ (Gambar 7b). Nilai koefisien negatif ini dianggap sebagai eksistensi dari pusaran arus (eddies) yang terbentuk di kedua kawasan itu.

Pola struktur spasial EOF mode-1 (Gambar 7a) diduga mencirikan karakteristik aliran Arlindo Makassar. Hal ini terlihat dari kesamaan pola yang terbentuk dengan arus meridional permukaan rata-rata (tidak disajikan). Pola tersebut memperlihatkan bahwa aliran utama Arlindo dominan menuju arah 

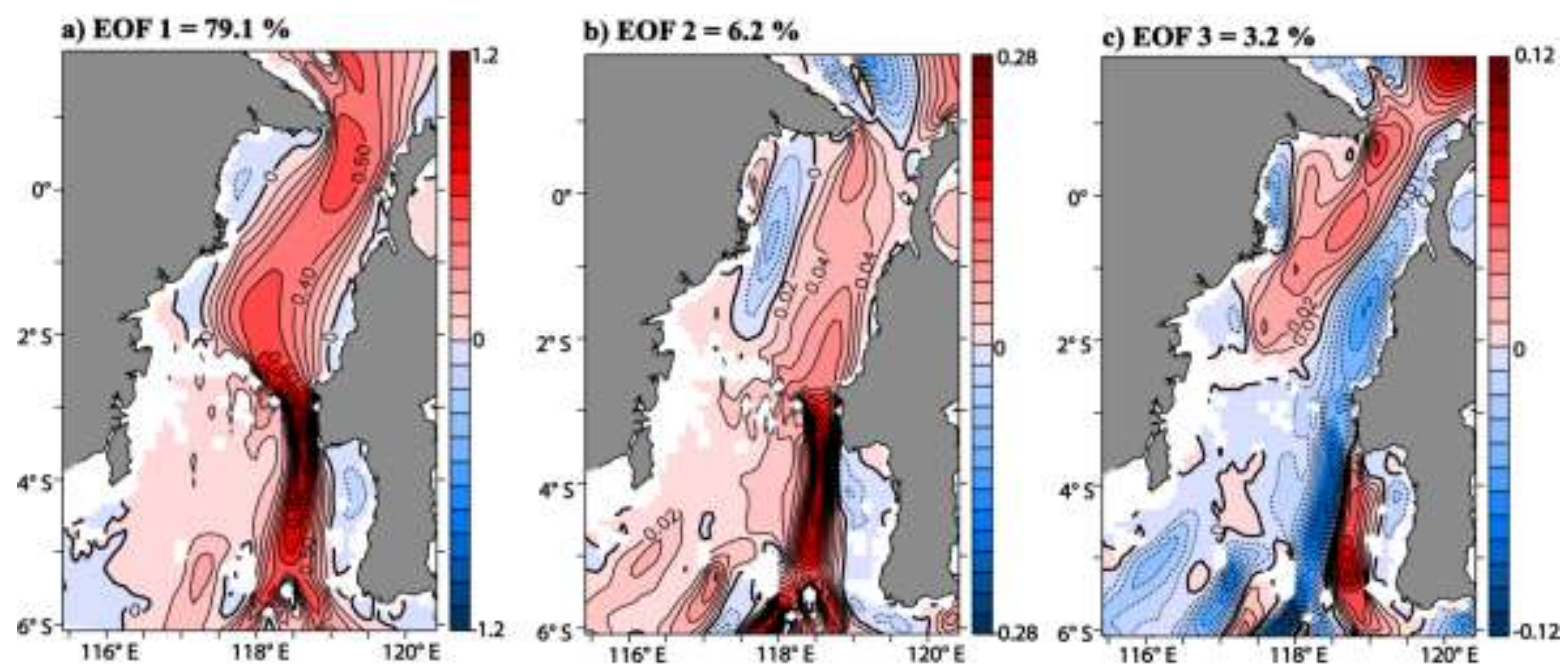

Gambar 7. Struktur spasial dari hasil analisis EOF untuk 3 Mode terbesar dari komponen arus meridional kedalaman $25 \mathrm{~m}$; (a) mode-1 dengan nilai explained variance sebesar 79\%; (b) mode-2 sekitar 6\%; dan (c) mode-3 sekitar 3.2\%.

selatan yang ditunjukan dengan nilai koefisien positif, sedangkan nilai negatif menunjukan resirkulasi arus. Amplitudo sinyal terbesar EOF mode-1 ditemukan pada pintu masuk Arlindo di utara SM dengan nilai mencapai 0.5 dan pada Kanal Libani dengan kisaran nilai sebesar 1. Hal ini sejalan dengan semakin tinggi standar deviasi arus meridional (v) di wilayah tersebut.

EOF mode-3 dengan besarnya explained variances $3.2 \%$ menunjukkan nilai koefisien EOF negatif di sebagian besar tepi timur selat, tetapi nilai koefisien positif ditemukan di sebagian tepi barat selat bagian utara (Gambar 7c). Pada mode-3 ini dapat diinterpretasikan bahwa fluktuasi Arlindo di bagian utara selat berlawanan fasenya dengan fluktuasi Arlindo di bagian selatan selat.

Variasi temporal dari Arlindo Makassar yang bersesuaian dengan 3 mode pertama tersebut disajikan pada Gambar 8. Pada principal component (PC) mode-1 fluktuasi temporal Arlindo Makassar yang dominan terjadi pada skala-waktu intra-musiman (periode 33-73 harian) yang tinggi dengan nilai koefisien CWT > 0.75 (Gambar 8b). Variabilitas intra-musiman yang tinggi ditemukan pada sekitar bulan Juni tahun 2008, Agustus 2009, November 2010 dan Juli 2012. Variabilitas intra-musiman Arlindo yang kuat di selat juga ditemukan Pujiana et al. (2012). Berdasarkan analisis PC mode-1 di kedalaman $25 \mathrm{~m}$ (tidak disajikan) diketahui bahwa periode intra musiman 57 dan 73 harian memiliki nilai energi densitas yang lebih besar yakni 1.4 dan $1.5(\mathrm{~m} / \mathrm{s})^{2}$ periode $^{-1}$. Periode 73 harian diduga dipengaruhi oleh kedatangan gelombang Kelvin intra-musiman yang memiliki periode 20-90 harian (Susanto et al., 2000; Qiu et al., 1999; Sprintall et al., 2000). Hasil penelitian terbaru dengan menggunakan data mooring arus pada dua lokasi di Kanal Libani juga menemukan adanya intrusi gelombang Kelvin yang berasal dari Samudera Hindia dari EOF mode-1 (45 \%) (Susanto et al., 2012).

Fluktuasi tahunan ditemukan pada PC mode-1 (Gambar 8a). Pola inter-annual yang ditemukan pada fluktuasi PC mode-1 (Gambar 8a, garis merah) berkorelasi dengan fluktuasi indeks ENSO. Anomali arus meridional (v) pada PC mode-1 menunjukkan beberapa puncak pada anomali dengan nilai $>-1$. Puncak yang tinggi (anomali $>-0.8$ ) terjadi pada sekitar November 2007-April 2008, Desember 2010-September 2011 dan Februari 2011-Maret 2011, sedangkan puncak yang rendah $(-1<$ anomali $<0.8)$ terjadi pada awal 2007, dan Juni 2009-Mei 2010. Nilai anomali $<-1$ dominan terjadi pada 

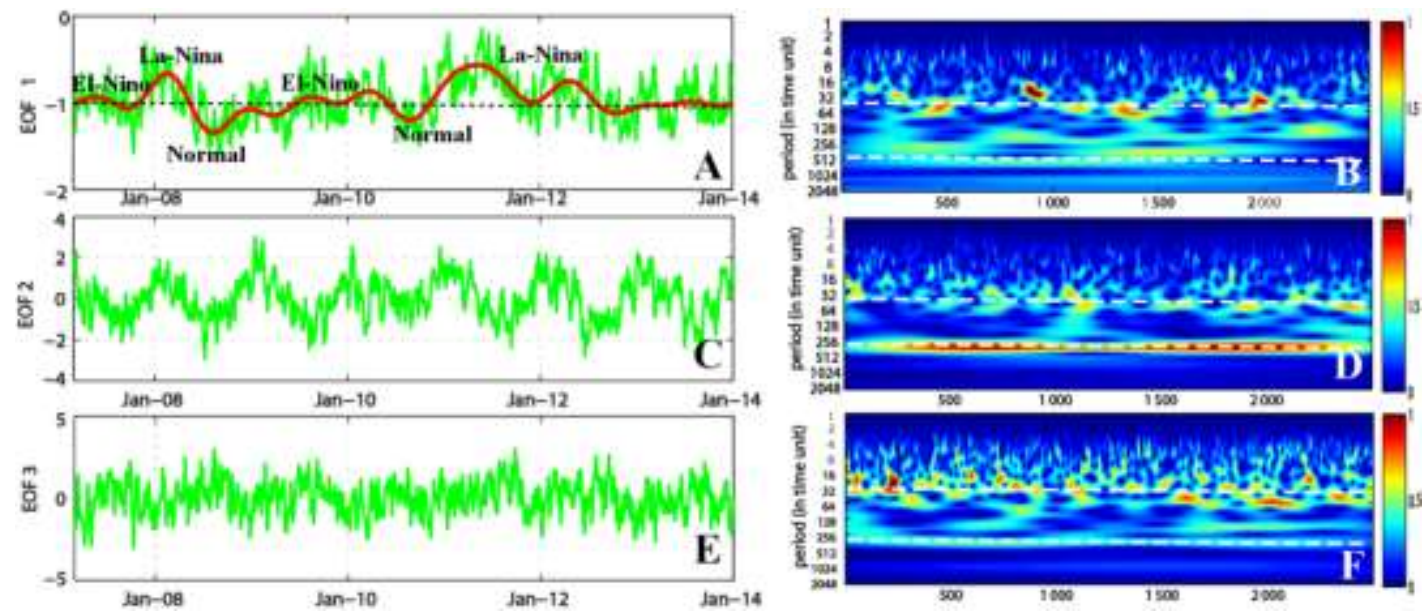

Gambar 8. Fluktuasi temporal principal component (PC) untuk 3 mode terbesar (kiri), dan hasil analisis transformasi wavelet dari deret-waktu yang bersesuaian (kanan) dari komponen arus meridional di kedalaman 25 m, (a-b) PC mode-1, (c-d) PC mode2, (c-d) PC mode-3.

Sekitar Mei 2008-Juni 2009, Juni 2010Oktober 2010, Juli 2012-Desember 2013.

Fluktuasi temporal PC mode-1 tersebut ditumpang-susun dengan indeks Nino 3.4, diperoleh sebaran temporal dengan puncak anomali $>-0.8$ bersesuaian dengan terjadinya La Nina, sebaran temporal dengan -1 $<$ anomali $<0.8$ diindikasikan sebagai waktu kejadian El Nino, sedangkan sebaran temporal dengan anomali $<-1$ diindikasikan dengan kejadian bukan tahun ENSO (normal). Fenomena ENSO di Selat Makassar dapat dikenali dari variabilitas suhu air laut (Ffield et al., 2000; Susanto et al., 2012). Pada komponen arus meridional (v) dekat permukaan, signal ENSO juga dapat dikenali dari PC mode-2 di kedalaman dekat permukaan (Gambar 8b).

Secara temporal melalui analisis transformasi wavelet (CWT) (Gambar 8c) diketahui bahwa periode intra-musiman masih terlihat namun dengan koefisisen wavelet yang lebih kecil. Sebaran koefisien CWT dan grafik temporal PC mode-2 menunjukan fluktuasi arus meridional dengan periodisitas dominan tahunan (Gambar 8c-d). amplitude fluktuasi anomali pada PC mode-2 lebih besar dibandingkan pada PC mode-3. Hal tersebut disebabkan karena PC mode-3 di dekat permukaan menunjukkan fluktuasi dalam periode intra-musiman yang cukup besar dengan puncak periode berada pada 64 dan 34 harian.

Grafik sebaran temporal dan analisis CWT menunjukan sinyal yang lemah pada PC mode- 2 dan mode-3 terjadi selama Juni 2009-Mei 2010 (Gambar 8c,e) atau pada periode terjadinya El Nino yang ditemukan pada PC mode-1 dimana variabilitas tahunan juga masih dimodulasi oleh variabilitas antartahunan (ENSO). Fluktuasi signal pada periode antar-tahunan juga ditemukan pada hasil analisis spektral (tidak diperlihatkan). Arus meridional Arlindo Makassar melemah dalam tahun El Nino. Hasil ini sejalan dengan penelitian sebelumnya, dimana El Nino berperan dalam mengurangi kontribusi Arlindo Makassar, sedangkan pada tahun La Nina, aliran Arlindo Makassar mengalami penguatan (Kindle et al., 1989; Ffield et al., 2000; Gordon et al., 2012; Sprintall et al., 2014).

Fluktuasi tahunan yang ditemukan pada PC mode-2 menampilkan nilai maksimum pada sekitar Musim Barat dan nilai minimum pada Musim Timur. Pada PC mode-3, ditemukan hal yang sebaliknya. Hal ini bersesuaian dengan komponen arus meridional yang menguat selama Musim Timur, dan melemah selama Musim Barat. Siklus tahunan ini masih teridentifikasi hingga bagian 
selatan SM pada jalur keluar Arlindo hingga mencapai Laut Jawa (Atmadipoera et al., 2009; Syahdan et al., 2015).

\subsubsection{Kedalaman Termoklin ( $92 \mathrm{~m})$}

Struktur spasial EOF mode-1, mode-2 dan mode-3 dengan nilai kontribusi explained variances sebesar $93.2 \%$ pada kedalaman termoklin ini disajikan pada Gambar 9. EOF mode-1 memiliki explained variance sebesar $85.5 \%$. Secara spasial koefisien positif yang ditujukan EOF mode-1 bersesuaian dengan aliran utama Arlindo Makasar (Gambar 9a). Hal ini terlihat dari struktur spasial EOF yang mirip dengan pola rerata arus meridional termoklin (tidak disajikan). EOF mode-1 memiliki nilai koefisien positif yang diduga mewakili jalur utama pergerakan Arlindo Makassar baik pada permukaan, kedalaman termoklin maupun kedalaman di bawah termoklin, sedangkan nilai koefisien negatif ditemukan pada wilayah tepi selat dan wilayah pembentukan eddies. Hasil EOF mode-1 menunjukan intensifikasi koefisien EOF positif di sisi barat SM pada posisi antara 0.1$2^{\circ} \mathrm{LS}$. Hal ini sejalan dengan hasil Mayer dan Damm (2012) mengenai intensifikasi jet seperti western boundary current yang mendo- rong massa air Arlindo ke arah barat sepanjang lintasan Arlindo di SM, serta hasil obsevasi arus SM pada Ekepedisis Widya Nusantara/EWIN selama bulan Juni tahun 2013 (Horhoruw et al., 2015). Nilai koefisien negatif pada EOF mode-1 diindikasikan sebagai resirkulasi dari arus meridional yang melewati selat (Gambar 9a).

EOF mode-2 pada lapisan termoklin dengan nilai explained variance $3.9 \%$, (Gambar 9b) menampilkan pola sebaran yang sama dengan EOF mode-2 pada kedalaman bawah bermoklin (Gambar 11b) yakni ditemukan adanya koefisien EOF dengan nilai positif dan negatif yang besar pada wilayah utara yang menunjukan besarnya anomali arus pada jalur masuk Arlindo Makassar namun dengan fase yang berlawanan. Hal ini sejalan dengan energi kinetik di kedalaman termoklin yang memiliki nilai yang besar pada wilayah utara (Gambar 14). Selanjutnya juga ditemukan koefisien EOF negatif yang besar pada wilayah Kanal Libani. EOF mode-2 pada lapisan termoklin berbeda dengan EOF mode-2 pada lapisan permukaan (Gambar 7b) dimana nilai EOF mode-2 pada lapisan termoklin bernilai dominan negatif,
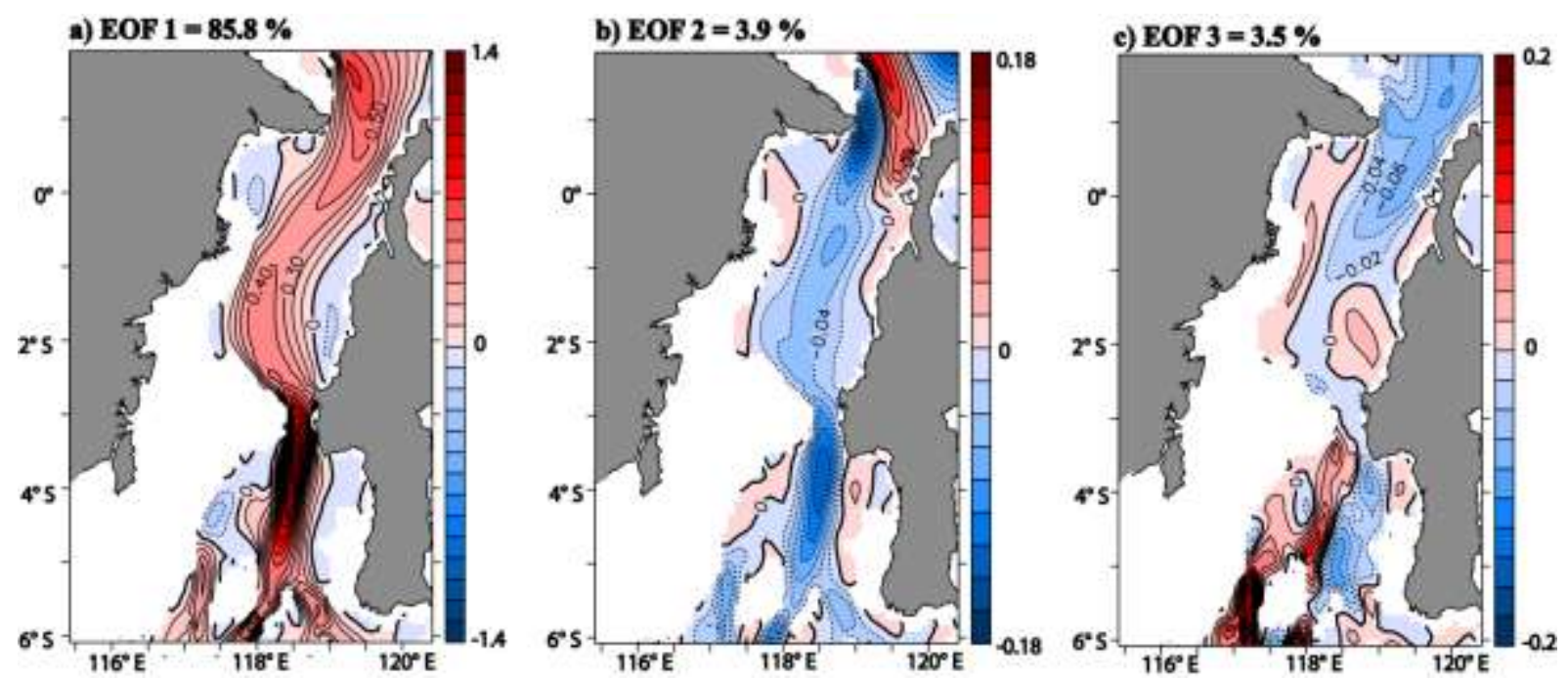

Gambar 9. Struktur spasial dari hasil analisis EOF untuk komponen arus meridional kedalaman $92 \mathrm{~m}$; (a) mode-1 dengan nilai explained variance sebesar 86\%; (b) mode-2 sekitar 4\%; dan (c) mode-3 sekitar 3.5\%. 
sedangkan pada lapisan permukaan memiliki nilai dominan positif.

Periode intra-musiman ditemukan cukup signifikan dengan puncak periode 32-64 harian pada EOF mode-2 dengan besar energi spektral masing-masing 26 dan 36.7 $(\mathrm{m} / \mathrm{s})^{2}$ periode $^{-1}$ (tidak disajikan). Signal intra-musiman tersebut diduga merupakan hasil perambatan Gelombang Rossby yang berasal dari Samudera Pasifik melalui Laut Sulawesi. Gelombang ini memiliki periode 35-60 harian (Qiu et al., 1999; Kashino et al., 1999). Grafik osilasi EOF mode-2 (Gambar 10c), menunjukan bahwa pengaruh ENSO telah berkurang dibandingkan pada EOF mode-1, yang disebabkan menguatnya periode tahunan pada EOF mode-2. Periode 2147 harian yang ditemukan pada EOF di kedalaman termoklin (mode-1, mode-2 dan mode-3) turut memberikan pengaruh pada variabilitas yang terjadi di selat. Menurut Pujiana et al. (2012) variabilitas intramusiman dengan puncak antara 20-40 harian merupakan representasi dari eddy siklonik dan anti siklonik di selat.

EOF mode- 3 dengan explained variance $3.5 \%$ menunjukan pengaruh kuat variabilitas tahunan dimana variabilitas lainnya bernilai lebih kecil (Gambar 10e). Variabilitas tahunan arus meridional pada kedalaman termoklin memiliki kekuatan maksimum pada Musim Timur serta minimum pada Musim Barat.

\subsubsection{Kedalaman Bawah Termoklin ( 318 m)}

Sebaran koefisien EOF pada kedalaman bawah termoklin (Gambar 11a) menunjukan EOF mode-1 $(87.3 \%$ explained variance) memiliki pola sebaran mirip seperti pada kedalaman permukaan maupun termoklin, namun dengan nilai sebaran koefisien EOF yang lebih kecil dibandingkan pada kedua kedalaman lainnya. Hal ini sejalan dengan semakin kecilnya arus pada kedalaman bawah termoklin.

EOF mode-2 dan mode-3 (Gambar 11 b, c) di kedalaman bawah termoklin menunjukan koefisien EOF yang positif. Koefisien terkuat ditemukan pada wilayah utara baik yang bernilai positif maupun negatif dan pada wilayah Kanal Libani.

Osilasi anomali EOF mode-1 di kedalaman bawah termoklin berbeda bila dibandingkan dengan EOF mode-1 pada kedalaman permukaan dan termoklin. Berda-
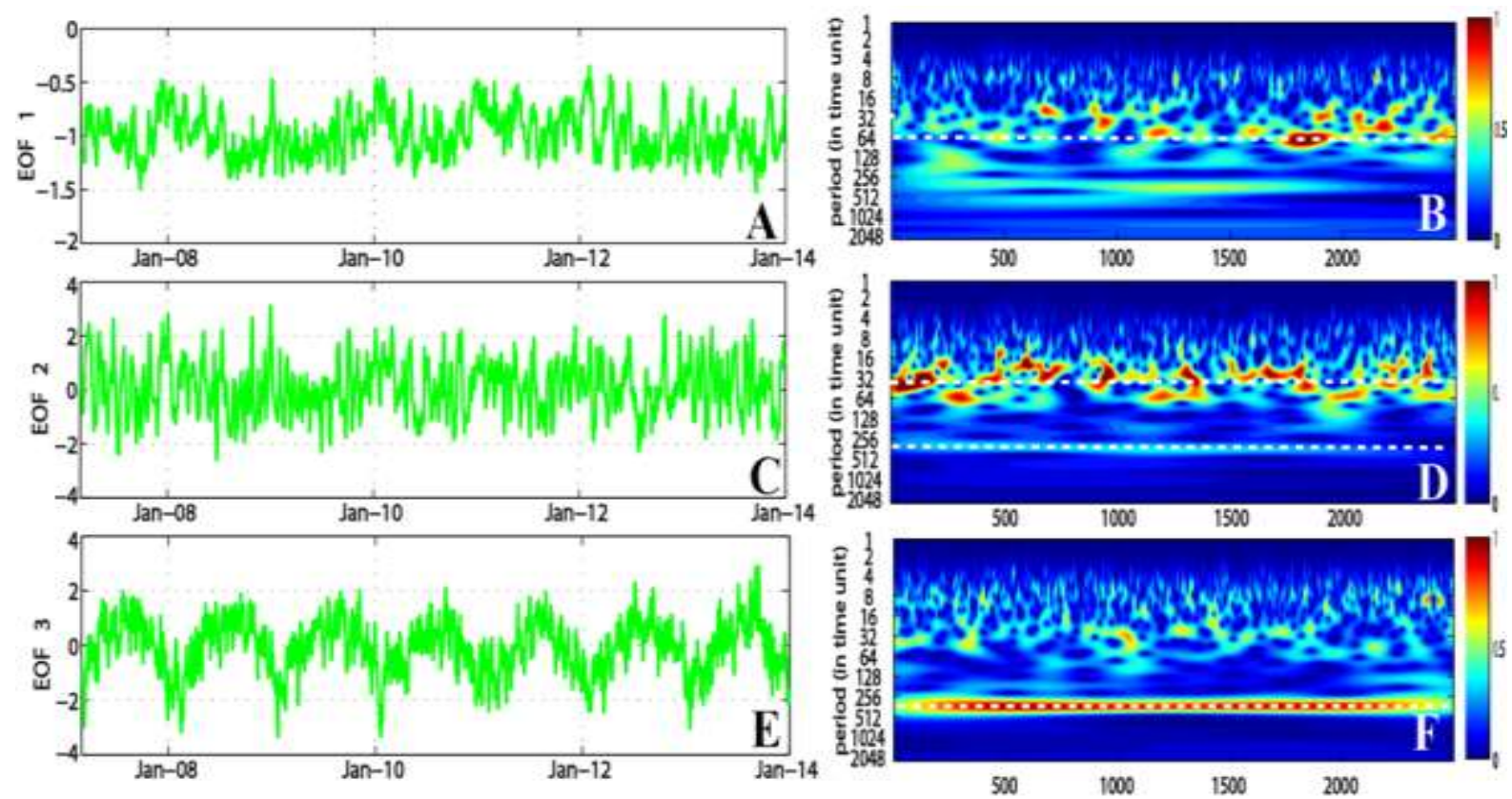

Gambar 10. Seperti pada Gambar 7, tapi di kedalaman 92 m (termoklin). 

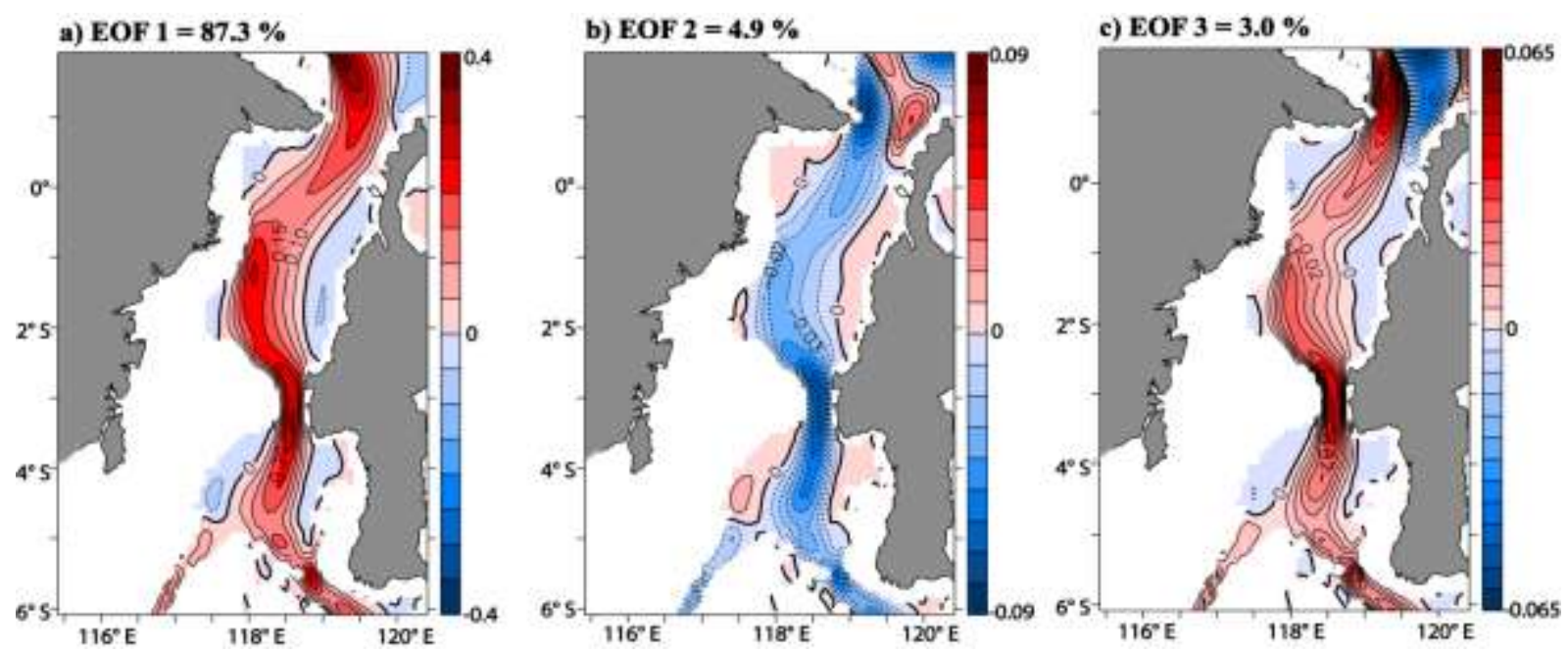

Gambar 11. Struktur spasial dari hasil analisis EOF untuk komponen arus meridional pada kedalaman $312 \mathrm{~m}$; (a) mode-1 dengan nilai explained variance sebesar 87.3\%; (b) mode-2 sekitar $4.4 \%$; dan (c) mode-3 sekitar 3\%.

sarkan grafik sebaran temporal EOF pada kedalaman bawah termoklin (Gambar 12a) ditemukan variabilitas intra-musiman yang diketahui dari analisis CWT (Gambar 12b) dengan periode sebesar 51 harian. Penelitian sebelumnya menggunakan data selama 1.5 tahun (1996-1998) di kedalaman 300-450 mendapatkan dua variabilitas intra-musiman yang signifikan di selat dengan puncak 36-60 dan 70-100 harian (Susanto et al., 2000). Osilasi 50 harian juga ditemukan Qiu et al. (1999).

Pola osilasi EOF mode-1 pada Gambar 12a menunjukkan variabilitas tahunan yang tidak teratur. Hal ini disebabkan oleh pengaruh variabilitas antar-tahunan 512 harian yang juga terdeteksi dengan analisis spektral (tidak disajikan). Variabilitas intra tahunan terdeteksi pada tahun awal (20072008) dan akhir (2011-2013) pada analisis CWT (Gambar 12b).

Variabilitas intra-musiman ditemukan secara tegas pada EOF mode-2 (51 dan 60 harian) dengan nilai explained variance $4.4 \%$ di kedalaman bawah termoklin (Gambar 12d) dengan energi densitas masing-masing 50.4 dan $49.8(\mathrm{~m} / \mathrm{s})^{2}$ periode $^{-1}$ (tidak disajikan). Periode 51 harian juga ditemukan pada EOF mode-1. Variabilitas intra-musiman arus meridional di selat diduga berkorelasi dengan dinamika arus di Samudera Hindia melalui penjalaran signal gelombang Kelvin yang masuk melalui Selat Lombok, serta gelombang Rossby yang berasal dari Samudera Pasifik (Susanto et al., 2000). Variabilitas arus di selat yang ditemukan dengan periode 51 harian diduga akibat pengaruh perambatan gelombang Rossby, dimana gelombang ini teridentifikasi di Laut Sulawesi dengan periode osilasi 35-60 harian (Qiu et al., 1999; Kashino et al., 1999). Gelombang Rossby memberikan pengaruh yang signifikan terhadap variabilitas antar tahunan (Shinoda et al., 2012; Mc Clean et al., 2005; White et al., 2003). Selanjutnya Pujiana et al. (2009) menyatakan bahwa variabilitas intramusiman di selat juga dapat dimodulasi oleh eksistensi ENSO.

Analisis CWT pada EOF mode-3 dengan nilai explained variance $3.0 \%$ menunjukan tingginya koefisien pada periode intra-musiman (28 dan 60 harian), sub-semi tahunan (120 harian), hingga antar-tahunan (512 harian). EOF mode-3 di kedalaman bawah termoklin juga menunjukan adanya periode yang cukup signifikan pada rentang waktu semi-tahunan (102-128 harian) yang juga terlihat dari hasil analisis CWT pada Gambar 12f. Susanto et al. (2012) meyatakan periode semi-tahunan yang terjadi di selat 

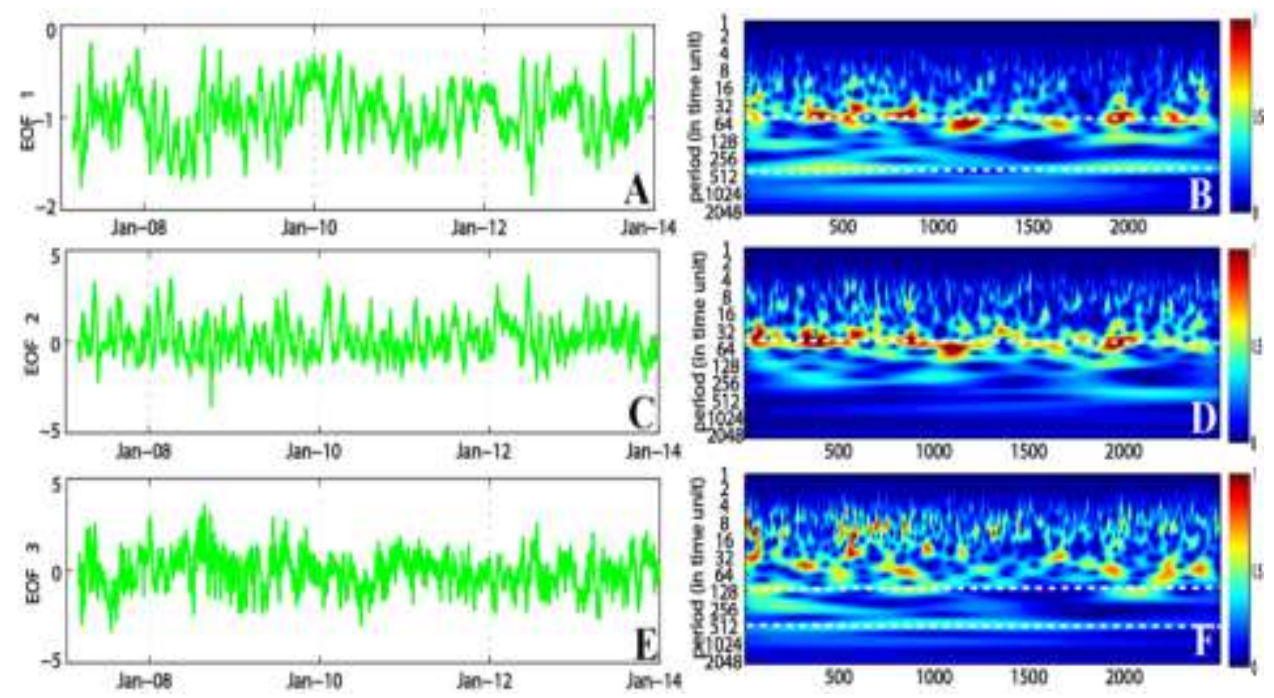

Gambar 12. Seperti pada Gambar 9, tapi di kedalaman 318 m (bawah termoklin).

berkaitan dengan gelombang Kelvin semitahunan dalam bulan Mei dan November. Adanya intrusi gelombang Kelvin semitahunan pada kedalaman bawah termoklin juga ditemukan pada grafik arus komponen meridional pada wilayah Kanal Libani (tidak ditampilkan). Pola berulang ditemukan dengan puncak nilai arus minimum yang ditandai dengan huruf pada grafik sebaran arus meridional selama musim peralihan. Studi sebelumnya menyatakan ada keterkaitan antara angin yang bertiup pada Samudera Hindia dengan variabilitas intra-musiman hingga semi-tahunan di selat (Qiu et al., 1999; Sprintall et al., 2000; Schiller et al., 2009). Intrusi signal gelombang Kelvin semitahunan yang berasal dari Samudera Hindia kedalam selat menyebabkan lemahnya Arlindo di kedalaman bawah termoklin.

\subsubsection{Koherensi Antara Arlindo Makas- sar dengan Arus Regional Indo- Pasifik}

Untuk memahami asal mula (origin) dari fluktuasi arus Arlindo Makassar, maka dilakukan analisis spektral silang (cross$P S D)$ antara fluktuasi arus Arlindo Makassar dengan sistem arus di kawasan Indo-Pasifik. Fluktuasi arus dinyatakan dengan flutuasi nilai energi kinetik (EK). Hasil analisis didapatkan nilai koherensi dan fase dari fluk- tuasi arus Arlindo makassar dan arus regional. Nilai koherensi menyatakan tingkat keeratan antara fluktuasi Arlindo Makassar dengan arus kawasan Indo-Pasifik, sedangkan besarnya sudut fase dari dua fluktuasi arus tersebut menyatakan selisih waktu dari kedua signal, yang bisa mendahului (lead) ataupun terlambat (lagged).

Hasil analisis spektral silang untuk arus sisi utara Selat Makassar dengan arus kawasan regional Indo-Pasifik di kedalaman $25 \mathrm{~m}$ (Gambar 13) dan di kedalaman $92 \mathrm{~m}$ (Gambar 14) pada periodisitas tahunan menunjukkan nilai koherensi yang signifikan (> 0.7) yang terbentuk utamanya di beberapa wilayah seperti di wilayah sistem arus tepi barat Pasifik, di lintasan barat Arlindo (Laut Sulawesi - Selat Makassar - Laut Flores - Selat Lombok) dan lintasan timur Arlindo (Laut Halmahera - Laut Seram - Laut Banda/Aru Celah Timor), serta di wilayah "muara" Arlindo di bagian basin Indo-Australia (IAB) Samudera Hindia (Gambar 13).

Wilayah tepi barat Pasifik ekuator dikenal sebagai wilayah pertemuan (confluence) dari arus tepi barat Pasifik lintang rendah (low latitude western boundary currents system - LLWBCs). Menurut Fine et al. (1994) dan Kashino et al. (2013), sistem arus di wilayah LLWBCs ini utamanya terdiri Arus Pantai New Guinea 


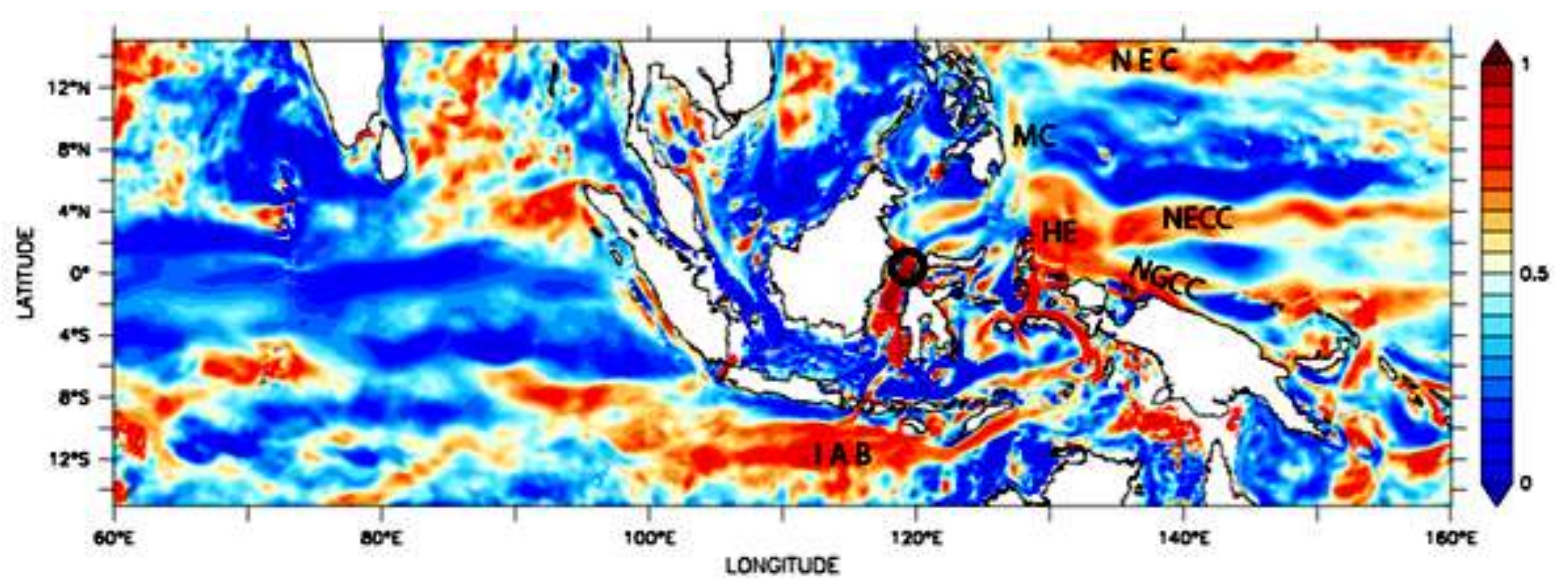

Gambar 13. Koherensi energi kinetik di kedalaman $25 \mathrm{~m}$ antara arus di bagian utara Selat Makassar (tanda lingkaran hitam) dengan arus regional Indo-Pasifik.

(NGCC) yang mengalir menyusuri punggung Papua kearah baratlaut, kemudian sebagian arus menyusup kedalam Laut Halmahera, dan sebagian besar berlanjut membentuk pusaran arus besar Halmahera Eddy (HE) karena bertemu dengan Arus Mindanao (MC) yang mengalir ke arah selatan di tepi timur Mindanao. Arus tersebut bergabung membentuk pangkal Arus Balik Ekuator Utara (NGCC) ke arah timur di sekitar lintang $4^{\circ}$ LU. Kedua, Arus Ekuator Utara (NEC) yang mengalir kearah barat di sepanjang lintang $15^{\circ} \mathrm{LU}$ sebagai bagian dari gyre $\mathrm{Pa}-$ sifik Utara. Arus ini membentur tepi timur Mindanao, yang kemudian mengalami divergensi sebagian besar arus mengalir kearah utara membentuk Arus Kuroshio dan sebagian mengalir ke arah selatan membentuk Arus Mindanao (MC). Arus Jet MC ini, seperti disebutkan di atas, mengalami bifurkasi di dekat pintu masuk timurlaut Laut Sulawesi, dimana sebagian aliran masuk ke Laut Sulawesi membentuk pangkal Arlindo yang terus berlanjut kearah Selat Makassar, dan sebagian lagi berbelok ke arah timur dan bertemu dengan arus NGCC yang membentuk pangkal arus NECC kearah timur.

Sistem arus di wilayah LLWBCs menunjukkan nilai koherensi yang tinggi dengan fluktuasi arus di Selat Makassar di kedalaman 25 m (Gambar 13). Namun demikian, asal mula dan mekanisme yang dapat menje- laskan terjadinya fluktuasi arus di Selat Makassar diduga lebih dipengaruhi secara langsung dari fluktuasi arus yang bersumber dari wilayah Pasifik utara (arus NEC dan arus MC), daripada fluktuasi arus dari Pasifik Selatan (NGCC). Hal ini karena Arlindo Makassar utamanya bersumber dari arus $\mathrm{Pa}$ sifik Utara (NEC dan MC), serta arus NGCC tidak secara langsung mengalir ke arah Laut Sulawesi tetapi mengalami retrofreksi ke arah timur dari HE menjadi NECC (Gambar 13). Demikian juga dengan nilai koherensi tinggi antara fluktuasi arus di Arlindo Makassar dengan fluktuasi arus di jalur timur Arlindo yang masuk dari Laut Halmahera Laut Seram - Laut Banda - Timor/OmbaiSamudera Hindia.

Koherensi arus di kedalaman $92 \mathrm{~m}$ (lapisan termoklin) pada periodisitas tahunan mempertegas Gambar 14, dimana nilai koherensi yang signifikan (>0.7) terjadi di sepanjang lintasan barat Arlindo, yang dimulai dari wilayah NEC - MC - Arlindo Sulawesi Arlindo Makassar - Arlindo Lombok - dan muara Arlindo di basin Indo-Australia (IAB), serta di lintasan timur Arlindo, dari sisi Sangir-Talaud - Laut Maluku - Laut Seram sisi timur Banda - Laut Timor - Samudera Hindia (IAB) (Gambar 14).

Dari nilai fasenya (tidak ditampilkan) fluktuasi Arlindo Makassar di level kedalaman 92 m (lingkaran hitam di Gambar 14) 


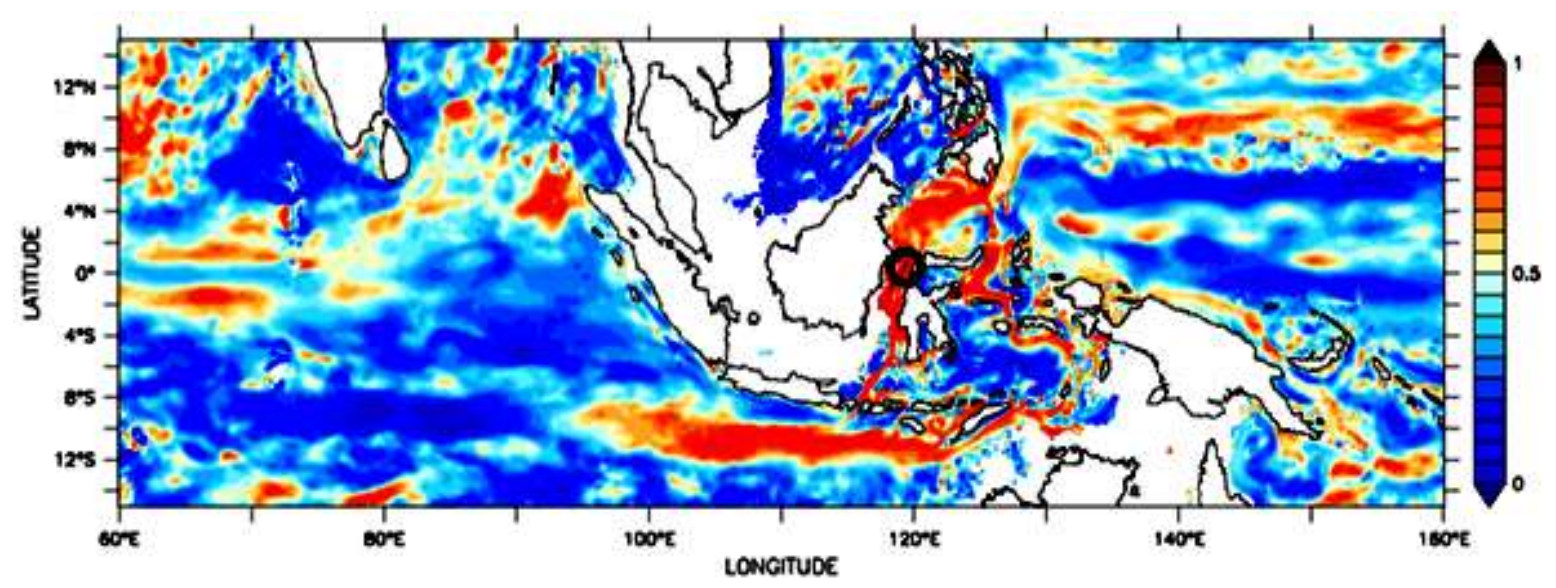

Gambar 14. Koherensi energi kinetik di kedalaman $92 \mathrm{~m}$ dari arus di bagian utara Selat Makassar (tanda lingkaran hitam) dengan arus regional Indo-Pasifik.

menunjukkan nilai tertinggal (lagged) dengan fluktuasi arus di Laut Sulawesi, MC dan NEC, sehingga dapat diduga bahwa fluktuasi Arlindo Makassar secara langsung dipengaruhi oleh signal arus yang berasal dari NEC. Pada fluktuasi skala intraseasonal, mekanisme perambatan signal arus dari NEC ke Makassar tersebut diduga melalui penjalaran gelombang Rosbby (Masumoto et al., 2001; Kashino et al., 2009; Qiu et al., 1999). Fase signal arus di bagian utara Makassar menunjukkan fase mendahului (lead) terhadap signal arus kearah selatan Makassar - Selat Lombok - Samudera Hindia.

Dari uraian di atas dapat dirangkum bahwa fluktuasi Arlindo Makassar di pintu utara selat menunjukkan koherensi yang signifikan dengan fluktuasi arus di sepanjang lintasan utama Arlindo yang bersumber dari perturbasi arus di wilayah NEC. Signal arus di utara Makassar menunjukkan fase tertinggal (lagged) ke arah Laut Sulawesi dan Pasifik, tetapi signal arus fase mendahului ke arah selatan Selat Makassar, Lombok dan Samudera Hindia. Hal ini diduga asal mula (origin) fluktuasi Arlindo Makassar di dekat pintu masuk utara selat bersumber utamanya dari Pasifik. Hasil analisis spektral silang antara Arlindo Makassar di selatan Kanal Libani ( $\left.4^{\circ} \mathrm{LS}\right)$ dengan arus Indo-Pasifik menunjukkan nilai koherensi yang kuat kearah ekuator Samudera Hindia dengan signal fase tertinggal di Makassar terhadap signal arus di Samudera Hindia, namun lemah kearah Pasifik (tidak ditampilkan). Hal ini sejalan dengan hasil penelitian sebelumnya yang melaporkan perambatan gelombang coastally traped gelombang Kelvin dari ekuator Hindia ke wilayah selatan Selat Makassar (Sprintall et al., 2000; Syamsudin et al., 2004; Susanto et al., 2012; Pujiana et al., 2013). Koherensi yang lemah dari arus di selatan kanal Libani terhadap arus di Pasifik diduga karena adanya peredaman signal oleh shear atau energi kinetik yang kuat di sekitar Kanal Libani karena terjadi penyempitan topografi selat (Gambar 6).

\section{KESIMPULAN}

Siklus tahunan Arlindo Makassar dicirikan oleh besaran kecepatan aliran dan lebar Jet Arlindo Makassar yang lebih kuat pada Musim Timur dibandingkan dengan Musim Barat, terbentuk pusaran arus (eddies) serta partisi cabang Arlindo di bagian selatan selat. Pola aliran Arlindo Makassar berkelokkelok mengikuti dangkalan Kalimantan di tepi barat selat. Energi kinetik (EK) yang tinggi (> $0.15 \mathrm{~m}^{2} / \mathrm{s}^{2}$ per unit massa) terbentuk di sepanjang sumbu utama aliran Arlindo Makassar sampai kedalaman bawah termoklin dan mencapai maksimum di lapisan ter- 
moklin, yang mengindikasikan magnitude kecepatan arus kuat dari Arlindo Makassar. Lonjakan EK yang drastis $\left(>0.7 \mathrm{~m}^{2} / \mathrm{s}^{2}\right.$ per unit massa) terjadi di sekitar Kanal Libani dari permukaan sampai kedalaman sekitar $200 \mathrm{~m}$. Penyempitan selat mengharuskan terjadi lonjakan kecepatan aliran supaya debit Arlindo sebelum masuk kanal sama dengan debit aliran di dalam kanal. Kecepatan maksimum aliran Arlindo di Kanal Libani mencapai $1.2 \mathrm{~m} / \mathrm{s}$.

Struktur spasial Arlindo Makassar di lapisan dekat permukaan $(25 \mathrm{~m})$ dapat dijelaskan dari EOF mode-1 dengan total explained variance sebesar $79 \%$ yang dicirikan dengan distribusi koefisien EOF positif di sepanjang sumbu utama alirannya, serta koefisien EOF negatif di sekitar wilayah pembentukan eddies di tepi barat (sekitar $1^{\circ} \mathrm{LU}$ ) dan tepi timur selat (sekitar $4^{\circ} \mathrm{LS}$ ), yang menunjukkan fase berlawanan antara fluktuasi Arlindo Makassar dan sirkulasi eddies di pinggir selat. Peningkatan koefisien EOF positif terbentuk di sekitar Kanal Libani. Variasi temporal dari principal component mode-1 pada kedalaman $25 \mathrm{~m}$ tersebut menunjukkan variabilitas Arlindo dalam skala-waktu intra-musiman dan antartahunan. Fluktuasi Arlindo skala tahunan muncul secara tegas pada PC mode-2. Di lapisan termoklin $(92 \mathrm{~m})$ dan bawah termoklin $(318 \mathrm{~m})$, struktur spasial dan variasi temporal dari hasil analisis EOF untuk Arlindo Makassar hampir mirip polanya.

Di dekat permukaan $(25 \mathrm{~m})$ koherensi yang tinggi (> 0.7) terjadi antara fluktuasi Arlindo Makassar di dekat pintu utara selat dengan fluktuasi arus-arus di wilayah regional low latitude western boundary current. Di lapisan termoklin (92 m) koherensi yang tinggi tersebut lebih spesifik terbentuk antara Arlindo Makassar dengan sistem Arus Ekuator Utara (NEC), Arus Mindanao (MC) dan Arlindo Sulawesi. Sehingga dapat dikatakan bahwa variabilitas Arlindo Makassar di dekat pintu utara selat dipengaruhi oleh fluktuasi sistem arus dari barat tropis Pasifik, seperti NEC dan MC.

\section{UCAPAN TERIMA KASIH}

Penulis menghaturkan ucapan terima kasih kepada berbagai pihak yang telah membantu dan memfasilitasi riset ini. Secara khusus penulis sampaikan terima kasih kepada INDESO Project Office: Dr. Phillipe Gaspar, Dr. Benoit Tranchant dan Dr. Ariane Koch-Larrouy, serta Berny Subki MSc, yang telah memberikan akses data hasil simulasi INDESO (2008-2014). Ucapan terima kasih juga disampaikan kepada Project Office Mercator-Ocean yang telah menyediakan keluaran model sirkulasi global. Komentar dan masukan yang berharga untuk penyempurnaan artikel ini dari para Mitra Bestari dihaturkan terima kasih.

\section{DAFTAR PUSTAKA}

Atmadipoera, A., R. Molcard, G. Madec, S. Wijffels, J. Sprintall, A. Koch-Larrouy, I. Jaya, and A. Supangat. 2009. Characteristics and variability of the Indonesian throughflow water at the outflow straits. Deep-Sea Res. I., 56: 1942-1954, doi:10.1016/j.dsr.2009. 06.004.

Atmadipoera, A.S. and P. Widyastuti. 2014. A numerical modeling study on upwelling mechanism in southern Makassar Strait. J. Ilmu dan Teknologi Kelautan Tropis, 6(2):355-371.

Bendat, J.S. and A.G. Piersol. 2000. Random data analysis and measurement procedures. John Wiley. New York. $387 \mathrm{p}$.

Fang, G., R.D. Susanto, S. Wirasantosa, F. Qiao, A. Supangat, B. Fan, Z. Wei, B. Sulistiyo, and S. Li. 2010. Volume, heat, and freshwater transport from the South China Sea to Indonesian seas in the boreal winter of 20072008. J. Geophys. Res., 115(C12020): 1-11, doi:10.1029/2010JC006225.

Ffield A., K. Vranes, A.L. Gordon, and R.D. Susanto. 2000. Temperature variability within Makassar Strait. J. Geo- 
phys. Res. Lett., 27(20):237-240.

Godfrey, J.S. 1996. The effect of the Indonesian throughflow on ocean circulation and heat exchange with the atmosphere: a review. J. Geophys. Res., 101:12.217-12.237.

Gordon, A.L. 1986. Interocean exchange of thermocline water. J. Geophys Res., 91:5037-5046.

Gordon, A.L., R.D. Susanto, K. Vranes. 2003. Cool Indonesian throughflow as a consequence of restricted surface layer flow. Nature, 425:824-828, doi: 10.1038 /nature02038.

Gordon, A.L. 2005. Oceanography of the Indonesian seas and their throughflow. Oceanogr., 18(4):14-27.

Gordon, A.L., B.A. Huber, E.J. Metzger, R.D. Susanto, H.E. Hulburt, R.T. Adi. 2012. South China Sea trhoughflow impact on the Indonesian throughflow. J. Geophys. Res., 39:1-7, doi:10.1029/2012GL052021.

Hanachi, A., I.T. Jolliffe, D.B. Stephenson. 2007. Empirical orthogonal function and related techniques in atmospheric science: a review. J. Climatology, 27: 1119-1152.

Horhoruw, S.M., A.S. Atmadipoera, M. Purba, and A. Purwandana. 2015. Struktur arus dan variasi spasial Arlindo di Selat Makassar dari Ewin 2013. Ilmu Kelautan, 20(2):87-100.

Ilahude, A.G., dan A. Nontji. 1993. Oseanografi Indonesia dan perubahan iklim global (El Nina dan La Nina). Disajikan dalam lokakarya kita dan perubahan iklim global: kasus El Nino - La Nina. Akademi Ilmu Pengetahuan. Jakarta. Hlm.:1-13.

Ilahude, A.G. and A.L. Gordon. 1996. Thermocline stratification within the Indonesian Seas. J. Geophys. Res., 101 (C5):12.401-12409, doi: 10.1029/95J $\mathrm{C} 03798$.

Kashino , Y., H. Watanabe, B. Herunadi, M. Aoyama, and D. Hartoyo. 1999. Current variability at the Pacific entrance of the Indonesian Through-flow. $J$. Geophys. Res., 15:11021-11035, doi: 10.1029/1999JC900033.

Kida, S. and S. Wijffels. 2012. The impact of the Indonesian throughflow and tidal mixing on the summertime sea surface temperature in the western Indonesian Seas. J. Geophys. Res., 117 (C09007):1-14, doi:10.1029/2012JC0 08162.

Kindle, J.C. and J.D. Thomsom. 1989. The 26- and 50-Day Oscillation in the Western Indian Ocean: modal result. J. Geophys. Res., 94(C4):4721-4736, doi:10.1029/ JC094iC04p04721.

Liu, Q.Y., M. Feng M., D. Wang, and S. Wijffels. 2015. Interannual variability of the Indonesian Throughflow transport: a revisit based on 30 year expendable baththermograph data. $J$. Geophys. Res., 120(12):8270-8282, doi:10.1002/2015JC011351.

Masumoto, Y., T. Kagimoto, M. Yoshida, M. Fukuda, N. Hirose, and T. Yamagata. 2001. Intraseasonal eddies in the Sulawesi Sea simulated in an ocean general circulation modal. Geophys. Res. Lett., 28(8):1631-1634.

Mayer, B. and P.E. Damm. 2012. The Makassar Strait throughflow and its jet. J. Geophys. Res., 117(C07020):114, doi:10.1029/2011JC007809.

Nababan, B., N. Rosyadi, D. Manurung, N.M.N. Natih, and R. Hakim. 2016. The seasonal variability of sea surface temperature and chlorophyll-a concentration in the southern Makassar Strait. Procedia Environmental Sciences, 330(2016):583-599.

Pujiana, K., A.L. Gordon, J. Sprintall, and R.D. Susanto. 2009. Intraseasonal variabillity in the Makassar Strait thermocline. J. Mar. Res., 67(6):757777, doi: 10.1357/002224009792006 115.

Pujiana, K., A.L. Gordon, E.J Metzger, and A.L. Ffield. 2012. The Makassar Strait pycnocline variability at $20-40$ 
days. Dyn. Atmosphere and Oceans., 53-54:17-35, doi:10.1016/j.dynatmo ce.2012.01.001

Qiu, B., M. Mao, and Y. Kashino. 1999. Intraseasonal variability in the IndoPacific throughflow and the regions surrounding the Indonesian Seas. $J$. Phys. Oceanogr., 29:1599-1618, doi: 10.1175/1520-0485.

Shinoda, T., W. Han, E.J. Mezger, and H.E. Hurlburt. 2012. Seasonal variation of Indonesian throughflow in Makassar Strait. J. Phys. Oceanogr., 42(7): 1099-1023, doi:10.1175/JPO-D-110120.1.

Sprintall, J., A.L. Gordon, R. Murtugudde, and R.D. Susanto. 2000. A semiannual Indian Ocean forced Kelvin wave observed in the Indonesian seas in May 1997. J. Geophys. Res., 105 (C7):17.217-17.230.

Sprintall, J., A.L. Gordon, A. Koch-Larrouy, T. Lee, J.T. Potemra, K. Pujiana, and S.E. Wijffels. 2014. The Indonesian seas and their role in the coupled ocean-climate system. Nature Geoscience, 7:487-492, doi:10.1038/NGE $\mathrm{O} 2188$.

Susanto, R.D., A.L. Gordon, J. Sprintall, and B. Herunadi. 2000. Intraseasonal variability and tides in Makassar Strait. $J$. Geophys. Res. Lett., 27: 1499-1502, doi:10.1029/2000GL011414.
Susanto, R.D., A. Ffield, A.L. Gordon, and T.R. Adi. 2012. Variability of Indonesian throughflow within Makassar Strait, 2004-2009. J. Geophys. Res., 117(C09013):1-16. doi:10.1029/2012 JC008096.

Syahdan, M., A.S. Atmadipoera, S.B. Susilo, and J. Lumban-Gaol. 2014. Variability of surface chlorophyll-a in the Makassar Strait - Java Sea, Indonesia. IJSBAR., 14(2):103-116.

Theetten, S., B. Thiebaul, F. Dumas, and J. Paul. 2014. Bmgtools: a Community tool to handle modal grid and bathymetry. Mercator Ocean - Quarterly Newsletter. 94-98pp.

Thomson, R.E. and W.J. Emery. 2014. Data analyis methods in physical oceanography. ( $3^{\text {rd }}$ Ed.). Elsevier, New York. 729 p.

Tranchant, B., G. Reffray, E. Greiner, D. Nugroho, A. Koch-Larrouy, and P. Gaspar. 2015. Evaluation of an operational ocean modal configu-ration at $1 / 12^{\circ}$ spatial resolution for the Indonesian seas - Part 1. Oce Phys Geosci Model Dev. Disc., 8:6611-6668.

\section{Diterima : 28 April 2016 \\ Direview : 17 Juni 2016 \\ Disetujui : 25 Juni 2016}

